\title{
ELECTRON MICROSCOPIC STUDIES ON THE SUPERIOR CERVICAL GANGLION OF GUINEA PIGS IN THE NORMAL AND EXPERIMENTAL REILLY'S PHAENOMENON
}

By

\author{
K. TAMAGAWA
}

From the Department of Oto-Rhino-Laryngology, School of Medicine Keio University (Director: Prof. T. Nishihatr)

The experimental studies to be presented in this paper were performed with a purpose of obtaining some informations about the relationship between Reilly's phenomena and morphological changes of the peripheral autonomic nerve cells under the observation with the electron-microscope.

First of all, the detail of the structure of the superior cervical ganglion cells of the guinea pig was studied and then changes in the structure of these cells were studied in two groups of animals. The first group contisted of those animals to which a minute amount of croton oil was injected beneath the mucous membrane of the lips and palate to bring the animal into a condition of shock. The animals of the second group were injected repeatedly with diluted croton oil and kept alive for twonty days.

In the superior cevical ganglion cells of the normal guinea pig, the endoplasmic reticulum which are visualized in the masses representing the Nissl's bodies are almost flat and arranged in a regular parallel fashion. Mitochondria, Golgi apparatus, neurofilaments, axonfibrils and infoldings of the cell membrane can also be visualized. Each nerve cell is surrounded by several capsular cells and each capsular cell is clearly delineated. Nucleoli were observed to consist not only of granular masses connecting nucleolonema but also of groups of fine granules which are present more abundantly around the area next to the nuclear membrane. Some interesting informations were also obtained of the structure of nucleoli and of nuclear membrane.

It is well documented in the observations with the conventional microscope that various stressful conditions induce chromatolysis. With the aid of the electron microscope, it was observed that in the animals of the second group, the chromatolysis is manifested as spreading, decrease in number or disappearance of the endoplasmic reticulum, and is aecompanied by convoluting of nuclei as well as various morphological changes of the nucleoli, whereas in the animals of the first group, no difference from the nomal morphology was observed. On the other hand, the histological picture of the tissue of the liver and kidney was the same in these two groups.

This result seems to indicate the participation of the superior cervical ganglion in the mechanism of maintaining homeostasis within the organism. The paucity of morphological changes in the ganglion cells of animals of the first group seems to indicate the condition before any morphological changes visible with the electron microscope could have taken place, and that under the conditions to which these animals were exposed, the stress affected the entire body so violently and rapidly that the ganglion cells had no time to show their reactions in their full extent before its fatal effect became manifested. 


\section{正常及び実験的レーリー現象におけるモルモット 上頸部交感神経節の電子顕微鏡的研究}

摩応義塾大学医学部耳鼻咽喉科学教室（主任 西端騑一教授）

助手 王 川

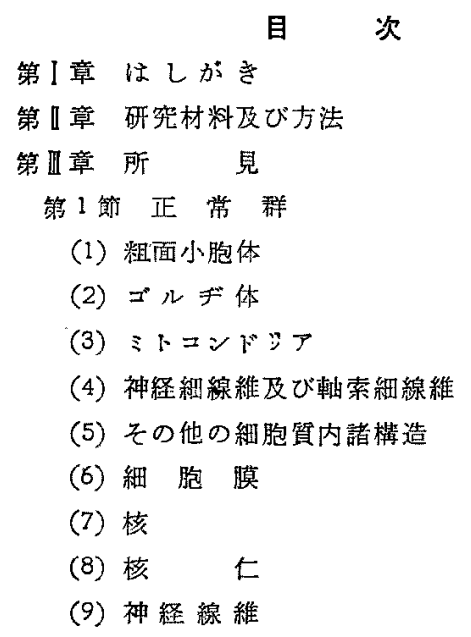

第 2 節 短時間 群

第 3 節 長時間群

（1）粗面小胞体

(2) エ゙ルヂ体

(3) ミトニンドシブ

(4) 神経細線雅及び軸索細線維

（5）その他の細胞質内諸棈造

(6) 湅 胞 膜

(7) 核

(8) 核仁

(9)神経楾 維

第 $\mathrm{N}$ 等 考察

第 1 節 粗面小胞体について

第 2 節 核について

第 3 節 核仁について

第 4 節 预物実験について

旌り章むすび

参考文献

\section{第I章はしがき}

近年, H. Selye 58) 59) の適応症候群は文はストレス学 説が，ACTH, Cortison の出現により実験的に里論ら゙
けられ，臨床医学に多大の貢献を遂げつょあるか゚，これ と並えで，1934 年以来の J. Reilly 68) 78) 80) の学説を裏 づけんとする矿究が，クロールブロマジン発見以来，急

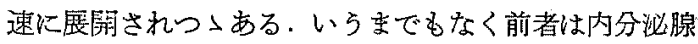

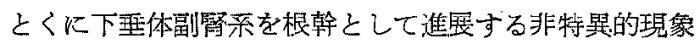
を何、究したすのであり，後都は植物神経系を少する非特 異的現象る論じたるのである.更に，H. Laborit は自 律祸経相，内分必相，体淮相上りする綜合理論を立て， 侵营によつて扎こる生体の反応に説明を加えたが，これ らの概合は次第に各印領域に和いて，重要視されつつあ る。

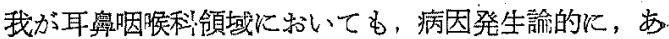
るいは病態生理学的にみて，このような立場から死究す べき多くの課題がある。特に臨床上時として遭遇するシ ヨックの出現が，統計的にみると我が利領域に想像以上 に多い69 ことに注目したい，しか子多の発生譏序に関， しては,なお不明といらべく, 種々の観点からら説明が為 されれていが，鈴木 ${ }^{70)}$ 等は自律神経遮断剂クロールプ ロマジンを使用して、ショッ多に陌つた患者の治療に極 めて好結果を得たことを報告し，植物神経の過剩刺战， 状態が何等かの役割を演ずるものであることを示唆し た。

これに関連して，当教室の飯田 ${ }^{29), \text { 深沢 }{ }^{25)} に よ る 「 モ ~}$ ルモツトロ蓋刺㦸によるショック様症状発現とその阻止 についての矿究」は，誠に與㸬深いものがある。

本看究の目的は，この奏験における植物神経の関与 を，電子蝢微鏡形態学的な表現として把握し得るかとう か、このために，上頸部交感神経節を撰び，その正常な 神経細胞の超微細構造を明らかにし，操作を加克たもの とを対比しつ入榆索して，こ礼らの所見を記戴しての変 化を検馀与ることにある。

さて，電子顕微鏡による細胞の形態学的的究は，彷 来, 殆ど正常な 細胞についての観寗にとら゙すていた が，多くの矿究者の努力により，広沉に互る技術的な制 約から㒖か乍ら解放されらっあり，これに伴い，最近に 
至つて漸く病的变化を追究せんとする試みが，内外の文 献に認められるといつた現状である・神経組䋨に関して 快, 神経線榷切断後に起る神経細胞の病変像の観察が 2

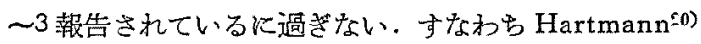
は，舌下神経核の神経細胞を，Causey $と$ Hoffmann ${ }^{11}$ は脊髄後根神経節を，Barton と Causey 2) は，上頸節 の変化を啹告した。

もとよりこれらはいずれも悡の行つた実験とは，趣 きを異にするものであるが，その病変像については類似 する点があり，一方正常な上頸節神経沺胞の超微細構造 恃，かなり私の所見之異る点がある，以下若干の知見 を，こ〉に報告し大方の御批判を仰ぐ次第である。

\section{第 II 章 研究材料及び方法}

実験材料火は 300〜350g の健康なモルモットを，特 、性別を考慮せずに使用した，又採り出した祎料は，正 一常群，短時間群，長時間群の三群に分けて，実験及び観 察を行つた.

正常群はモルモットの腹腔内に， $0.015 \mathrm{~g}$ のシボナー ルを $2 \mathrm{cc}$ の蒸溜水江溶解して注射，数分後全身麻酰の下 に, 頸部にメスを入れ，迷走神経を目標にして上頸節を 見出し素早く、こ和を摘出した。

短時間臂は飯田 299 の方法に従い，上記のモルモット を固定し，無麻酔の状態で，上日唇より口蓋にか汓て粘 膜下に䄪 $0.1 \mathrm{cc}$ のクロトン油原液を，徐々に注射した。 この際, 毎回注射針が血管内に入らないことを砝め, 又 注射後は特別の処置をほどこすことなく放置した。この 操作により，飯田の実験の上うに，約 $30 \sim 40$ 分後に， あるものはショック症状を呈する。この上うな症例のみ を撰び，そのモルモットの後頭部を桘にて叮打屡殺して 㨁らに上项節を摘出した，摘出に要した時間は曆殺啳 I 〜7 分であったが，熟達するに從い多くは2〜3 分以内 比切梌し得た。

長時間群は, 短時間群之同一の部位に, オレーフ油に て10倍に稀哷したクロトン油 $0.1 \mathrm{lcc}$ を同様の注意を払 つて注射乙，5 日後，10日後，15日後の計 4 回注射を 行い, 初回より20日後に、 フホナールによる全身麻醉 の下に上頸節の摘出した。

摘出した組織はいずれも，霜科用シーッワックス上に 滴下した固定液の中で， 30 秒以内に 6〜8 個隹細切し， 約 $0.5 \sim 1.0 \mathrm{~mm}^{3}$ の租織片を作り，これらを予的用意 したペニシリン嚗中に移し， $0^{\circ} \mathrm{C}$ にて 2 時間固定を行 つた. 固定液は Palade ${ }^{46)}$ の处方に従つて, AcetateVeronal により大体 pH 7.4 に緩衡した $1 \%$ オスミウム

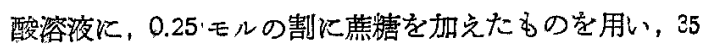
$\%$ 上り $100 \%$ に至る上昇アルニール系列にて脱水（各 々 30 分). 包埋には, n-butyl methacrylate $と$ metyl methacrylateを，7：3の割汇混合したるのを用い，重 合促進剂として過酸化べンゾィルを1\%の割に加え，約 ${ }^{50 \circ} \mathrm{C}$ の恒温器内にて重合を行つた.

超薄切片の作製には， Latta-Hartmann 型ガフスナ ナフを，その都度作り，島津型回転式ミクロトームに取 りつけて便用した。

切片は包理剤の除去を行わずに日立製 $\mathrm{HU} 10$ 型電子顕 微鏡を用いて観察した。

\section{第 1 節 正 常 群}

\section{第III章 所見}

弱拉大で見ると神経細胞は，円形，楕円形，紡錐形， 多角形など，かなり多様な形態が兒られ，その周囲は外 套細婿によつて取囲密れている．外套細胞質は一部では 薄いが，厚い部分もあり，その中に神経細胞の突起の断 面が見られ，文之の一極には外套細胞自身の核を持つ。 外套細胞は神経細胞との間に明磪な境界を持ち, 外套細 胞と外套細胞の境界る又明瞭で，一個の神経細胞が数個 の外套細胞により团をれていると思われ，末榆神経節の 外套細胞が，連続する一個の外套細胞細胞質に包泉え syncytial な構成をなすという本陣 24) の所見と全く異 る. 神経細胞の細胞質は辺縁厄て外套細胞の細胞質と互 に入り組んで，半島状に笑出あるいは彎入する複雔な断 面を呈する部分 (infolding) と，四突のない滑らかな翰 廓を有する部分とがある。核は多くは円形乃至棈円形で 1〜2 個を数克，核質は，注与均等江分布する微細な顆 粒状物質によつて満され，核膜により明らか汇細胞質と 区別される．核内に特有な構造を有する核仁が，1〜2 個認められる．細胞質内には一見濃染して見点る不規則 な塊状の部分が存しているが，これは電子密度大な小顆 粒及び小胞体の篦集したもので, 光学顕微鏡像の=シス ル小体に一致する部分と考えられている24) 53)。これら の集塊は細胞質の辺縁に特に豊富に認められ，互いに連 絡するものむあり，坬立性に分布するものも認められ， 細胞質の他の部分との間に，明鸲な境界構造を持たな い.な和, 電子密度の大きな円形又は棏状の多数のミト コンドシアが, ニッスル小体間の細胞質内に不規則に散 在するが, ニッスル小体内には，比輘的その分布が少 W.

以下強拡大下に認められた各部分の微細構造について 項を分けて記載する。 
（1）粗面小胞体 (rough surfaced endoplasmic reticulum)

細胞質内にかなり豊富に認められる構造ですでに多く の細胞で見出されている如く，一般に互いに平行して走 る2林の膜よりなり，この対をなした 2 枚の膜はその雨 端において，互いて連続することによつて小胞腔を形作 ク，細胞質の基質と㜧てられている．小胞腔は均質無構 造でその電子密度は，多くは周囲の細胞基質に比し萿し く小であり殆ど全く透明であるが，時に反刘に暗く見え ることがある，小胞腔の幅け一定しておらず，㹟い部分

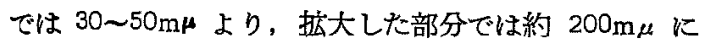
及ら゙すのを認めた，小胞腔を取囲さ膜，すなから小胞膜 の内面は常に平滑であるが，外面は電子密度の高い微細 な顆粒が附着して粗面をなすが，この顆粒の附艮の仕方 は，他の細胞の粗面小胞体に見られる様に，一蟹をなし て規則正しく附萇する部分を認めることもあるが，私の 钼察では，同一の小胞膜上で顆粒の附着する部分と欠除 する部分とが連繶していたり, 文顆粒の附着の少いもの がかなり多く見られる。基本的にはこの上らな構造を有 する粗面小胞体が，集簇的に分布する時乞の形態や配列 の仕方に多少の相異がある.ある部分では扁平の小胞体 が屬状に規則正しく配列する断面を示し，粗面小胞体間 の間隚及び小胞腔の幅も一様で，一部では互いに隣り合 つた 2 個の小胞体が物合したり分翄する像を示すが，全 体として大体に私いて平行性を維持している. 㕛別の部 分では，粗面小胞体が円形乃至棹状を呈するもの，ある いは不規則に屈曲したりくびれたり，更に千切れて小 空胞状を呈するものが認められる:

このよらに上頸節神経細胞内には豊富に小胞体が存在 し, その形態, 配列, 大きさ, 分布の仕方む加なり变化 に富もが，これらが泿在することは稀で，同一の細胞質 内でも，ある部分では整然と配列した構造を認め，これ と離れた別の部分では不規則な配列の集塊を認める。こ れら小胞体周辺の 細胞質の基質には直径 $200 \AA$ 前後の 細顆粒 (Palade の顆粒) が漸集しており，5〜7個の細 顆粒が集つて rosetteを形成するもの，円形文はンセン 形に配列するもの，文不規則に撒布するものがある，以 上の粗面小胞体並びに Palade の顆粒は主としてニッス ル小体に一致する部に存するが， Palade の顆粒は極め て粗ではあるがその他の 細胞啠の基質全体に認めら机 万.

(2) エ゚ルデ体

一般に神経細胞は，巨大なゴルデ体を有することが知
られており，電子顕微鏡下にもその一部を認めることが 出来る、ゴルデ体はニッスル小体の間の細胞質中に，ゴ ルヂ膜，ゴルヂ空胞，ゴルヂ顆粒の種々の配列，及び組 合せによつて構成される。すな市ら，よく発達したもの では，数個のプルヂ膜が平行に走り，密な厤状の配列を とり，しばしば極めて明るい無構造，類円形の部分によ り，この配列が不明瞭となる。文この尿状配列に従つて 一部に大小不定の大きさのゴルデ空胞が並ぶ.この他， ゴルデ膜が余り規則正しい开行を示さず砢合㕛は枝分れ したり，大小区ネの合珠状，あるいは葡萄状のゴルデ空 胞が不規則に集合するるのるすり，これらに附随してゴ ルヂ顆粒を認める。

(3) ミトニンドリア

細胞質の基筫中に，又は時として二ッスル小体の中に 包まれて, 円形, 長桿状, 稀にアメーバーよう不正形を 呈する多数のミトンンドリアが翟められる. その大きさ も種々であるが，一般に小さいものが多く，平均してそ の直惩は約 $200 \mathrm{~m} \mu$ であつた. 㕛ミネコンドシアの配列 や分布の仕方に一定の規則性を見出すことはできない が,たよ゙ニッスル小体中のミトコンド:アの数は, 細胞. 質基質中のbのに比して造かに分布が少いといらことが いえる・ミトコンドリアの微細構造については, すでに Palade 47) 48) や Sjöstrand 60)61) 62) 63) 等の方ぐれた确 究があるが，私の観察したものも住ざこれと同様の所見 を得た。すなわらミトニンドシアは二重の構造を有する 限界膜により包まれ平滑な外側膜によつて細胞質の基質 と完全に隔てられ，内側膜は比較的電子密度の高いミ下

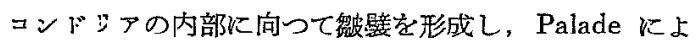
つて種々の細胞火認ぬられた Cristae mitochondriales の構造を有する.たら゙その並び方は，ミミュンドリアの 長軸に対して直角でないるのも多く，長軸に平行に突出 しているもの，又ミミニンドシナの基質中に円形又は扁 平の小胞状に坬立していて限界膜の関倸が，明らかでな いものも観察された、ミトニンドシアの基質内に，時と して電子密度の極めて高い均質無構造の顆粒を 1 -2 個 認める。

（4）神経細線維及び軹索細線維

神経細胞の突起部又は神絰線維が 緃断された切片で は、その韸にほら゙平行に走る锁細な線維構造を認めた。

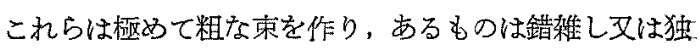
立してぼ゙一定の方向に向い滑らかな均買性の像を呈す る. 薄い切片又は切片の切れ方によつては，一溷の神経 細線維の走行を極めて短距離しか追らことができず，時 
机点状に見方る。その太さは約 100〜150A と测定され た。これは Palay 53) の認めた neurofilament に一致 するものと思就る。

（5）その他の細胞買内諸構造

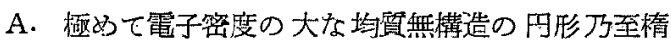
円形の小体が，細胞質内㳻在性汾分布する，その大き さは大体ミトコンドシフ程度のもので, 数はミトコンド シフに比し遥かに少く，大体 1：10位の割である。これ らは限界膜を持たず，しばしばその中心が円形に明るく 無構造で一見ドーナツ型を呈するものるあり，之の本体 屾六明である。

B. ミトニンドンアの程度の大きさで崛膫な単一の限

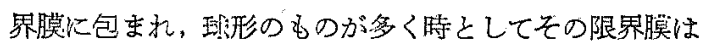
凹凹狊平で，その内部は:トニンドシアに比して遥かに 明るく全く拜構造であるか，又は内部に更に 円形の小 なる空胞を1〜数個保有する。これはヂルデ野に見られ るゴルデ空胞に 頪似するが，これと翼り特定の分布を 示さず，ゴルデ野以外の細胞質内にも坬立性に散在す る.

（6）細 胞 膜

神経細胞の 細胞質は明瞪な一蜜の膜によつて限罪さ れ，外套細胞の細胞膜との間に一定の幅の細胞間隚が存 する. 細胞膜は両面とも平滑で連続する一個の線として 観察され，その厚さは約 $50 \AA$, 細胞間坆の幅怯約 $150 \AA$ と湘定された。

(7) 核

良く固定された徱本では，核質内に極めて微細な顆柆 が，活ざ均等に充満してかり，核䐉によつて明らかに細 胞犋と区別される。核啠が細胞質に比して一見濃染し て見党るのは，この顆䊀の分布が密たからである，核 内には時として，その辺緑に円形文愉円形の集塊を なして，特に密にこの小顆粒が密集しているが，これ は，光学顕微鏡で見られるクロマテン顆粒あるいは， 口マテン網に相当するるのと思われる. 本神䌡細胞の 核償も又，すでに多くの細胞敒るられている通り，二 重膜構造を備卉，その内側の核朕はや〉厚く平滑で，非 薄な外側核膜との間に約 $200 \AA ̊ 丿$ の明るい均質な間淂を作 る. 外側核脱の 細胞質に接する面には顆粒の附着がな

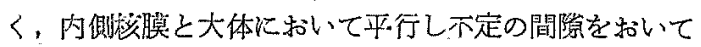

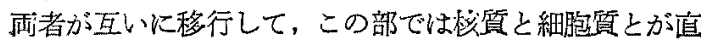
接々して括り，いわゆる㤥膜孔を形成する。核膜孔は時 として韭薄な膜によつて閉さされている如き像を呈す る.
(8) 瑢仁

棌仁は全体としてほよ゙先の輸廓は円形であるが、平滑 ではなく波状の粗大な四凸を示し，秢質との間汇は限界

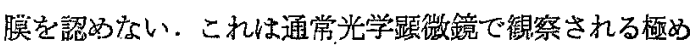
て明らかな球形の就仁とは全く趣きを異にする。薄い切 片を强拨大で見ると裉仁は極めて電子密度の高、微細顆 粒の集合体で，その集合の仕方により二種類に大別する ことができる。

第一は，これらの微細影粒が集合して米㲑状にからみ 合つた核仁系を形成しているもので，その一部では禒仁 米の販に対して，斜に平行して走る縞模様が形成され規 則正しい配列を思わせるが，多くはその配列状態は明ら かでない，核仁糸は複熦な分波吻合を形成しつつ網工を 作るため，断面に特いてその太さも一定せず細い部分む あり，太い部分も見られ，その伆合部で怢不正形の塊状 をなす，页同一の核仁でしばしば，秋仁系の電子密度に かなり大なる差異を認める。核仁糸と核仁糸の間の網腿 は，核質よりも明るいか汉同程度の電子密度を示し， 私はこの部分にも榕質と同様の微細顆粒が極方て粗に散 杕するのを認めた。

第二の清造は，注よ゙均等に集合した微細顆粒の塊状物 からなるもので，一罜無秩序に集合しているように見觉 るが，や〉厚い切片では規則正しく念珠状に配列する部 分も認められる.このような核仁は前述の網状構造に比 して一般に，顆粒の集合の仕方が粗であり，そのため全 体として電子密度が小である. しかもこの上うな核仁で も，網状構造の網眼に相当するような極めて明るい，す なわち顆粒分布の極めて粗な，部分が島状汇 1〜3個喼め られることがあり，专の大きさ，形状，部位等は不定で ある。

本神経細胞敒認められた核仁は，このような二種の構 造を示し，このらちたよ゙一檑の楧造のみからなるもの と，同一の核仁であり乍ら一部が網状で次第に又は突然 に塊状の部分の移行するもの，又同一の柿質内網状の 稴仁々塊状の核仁とが接して存在するものも見られる。 滺仁は核内に和いて，特定の位置を占めることなく絯の 辺縁に编すもの，圣核膜の内面に接着することもある が，この場合には核仁の核膜内面に近い部，特に接着し た部分には網状構造が倨暸でなく，不正形に突出した熄

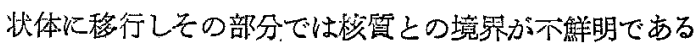
ことが多い。

(9) 神経線維

観察し得た上頸節内の神経線維は,すずて有輎無慨で 
ある・すなわらー個の神経袙維はその贀断面を見ると， 電子密菖の大な二重の薄膛に包まれ，その薄膜間の距襍 は約 $150 \AA$ と計測されはડ゙一定の愊を保ら明るく無構尷 である.内䁚の莫は閉鎖して完全に神注線濰を包もが， 外側朕は一部で外方へ翻枟し，Schwann E細砳賀内を 約 $150 \AA$ A の間區を維持しつ〉平行に走る二枚の薄慕，小 なわ占 Gasser 18) のいう mesaxon (結合膜) に連り，

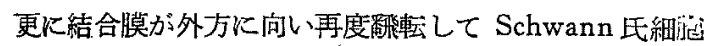
の細腿膜に移行することにより，この薄膜間の空䧊は細

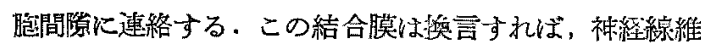
上Schwann 氏細胞膜上を連絡する膜で，Gasser 18)に

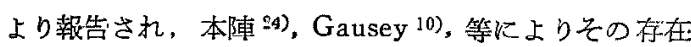

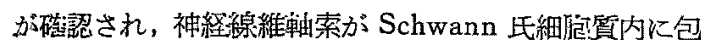

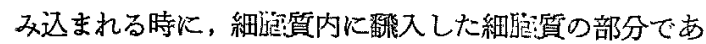
ろらといわれている。しばしばこの結合膜が，極めて短 いか文は全く無くて，单に一層の薄膜厄包まれた神䋨線

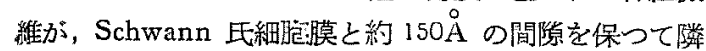
接している像が見られる。

福㳥線維の内部には，䩜索細線維：シトニンジタタが 認如られ，時としては数面小抱:体を認める。これらいず れる前述の搆造と同㥞であるが、ミ゙ンンドンアはツ形 乃至長棈円形のるが多い。

第2節 短時間群

一般にこの涪のものは，正常㴖との間に明らかな差異

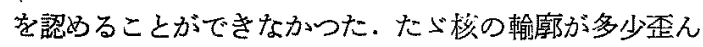
で、軽度な凹山の没状を呈するるのむ見られるが，全体 として円形乃至棈円形の比較的整つた形を失つておら ず,この程度の变形は正常詳にも敞見された。文, 核仁,

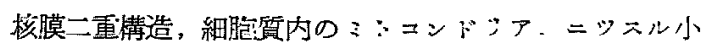
体、ゴルデ体その优の構造にも明らかな変化が認かられ ない.

第3節 長時間䐆

一見して神綾細胞:とその周囲の諸棈造に著しい変化そ 示すが，必ずしも一様でなく，部位によつてその程度 は様ヶである。低涪率では神経細脃と外套細胞との境界 が不明瞕なものが多い，同様の所見が細㴔の突起あるい は蚛経楾維上，外套細坨あるいは Schwann 氏細胞との 間にしばしば認められるが，一部ではこのような変化像 侮接して全く正常群と同様の画然として檴造さ保持し

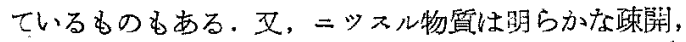

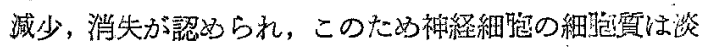
明化する傾问を示すが，一様でなく，一部にな打不正珠

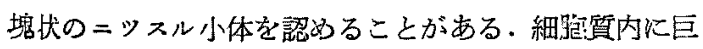
大な 不正形の 空脱を形成するものが少数作ら観察され
た.ミトコンドンアは形状, 数, 電子密度, 分布状態に 特に著しい変化を想めなかつた，核は輸廓が著しい歪形 を示すが，細航質との境星は核膜により鮮明に区別さ れ，核仁は增大しているものが圧倒的に多く，之の直径 が该の直径 $1 / 2 \sim 1 / 3$ に達するものを認好る．以下各部 分について記载する。

(1) 粗面你作 (rough surfaced endoplasmic reticulum)

光学顕微鏡下に，ニッスル小体が娍少消失の傾向を示

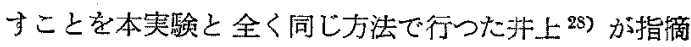
したように，電子䫓微鏡的にも，これに伴つて粗面小䏲 体及びその周团に密集する小顆粒が，減少消失し，この

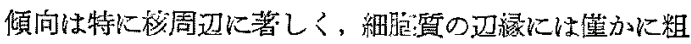
面小胞:体が塐存するのを認める。この場合，小顆粒は正

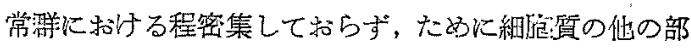
分上の間の密度の差が，比輁的少く，又これらの顆粒は 正常像のそれと同様 5〜7個がロゼッテを作り㕛はルー

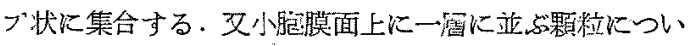
ても，正常像に芫ら机る通り規則正しく附着する部分も あるが，全くこれを欠拣可る部分も多い、粗面小腿体の

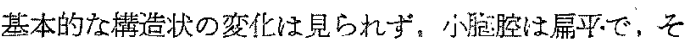
の幅は 30〜 $50 \mathrm{~m} \mu$ 程度であり，小䏸腔の膨化あるいは 臂子密度の変仩を示さない。

(2) ゴル ゙゙体

ゴルギ体は正常像においてすら多渌な形態をとるた わ，その病变時に特有な形態を握もことは六能であつ た、すなから正常像に見られる如く，相詨する二枚の薄 膜とその間腔からなる基本構造には変化がなく，滑面小 脯体の破摆像とか，薄膜閒腔の異常な膨化，拡大とか，

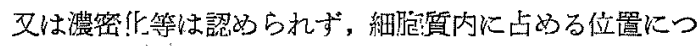
いても特異な所見は得られない。

(3) ミ:ニンドシ

ミミコントンアは, 大きさ, 形比, 分布については正 常の場合と異る所がない、ミミコンドンアの数は增加し

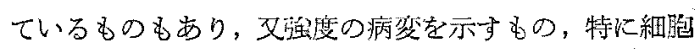

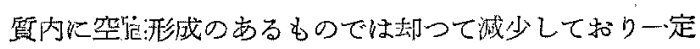

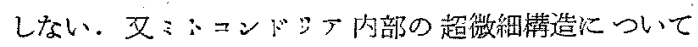

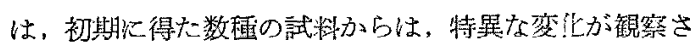

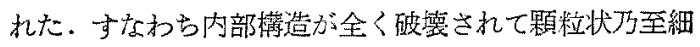
網状の物筫が，これに代つて:・ニンドンアの内部を波 すものがあつたが，その俟の電子顗微鏡写真からは，正 常のすのと全く变らない、Cristae mitochondriales 有 しミ:コンドンアの基質の電子密磨にも特に著しい変化 
を呈していないものが，多数見なれることから，この病 変像については，な招矿究の余地があり試料作製課程に 生じた人工産物という問題も考慮に入れなけ狄ばならな いと考光る。

(4)神経細線維及び軸索細線維

神経細線維を詳細に険べることはできなからたが，強 度の病変を呈する神経細腿内の神経細線維, 及び, その 附近を走る神経線維中の䩜索細線稚は多数が集つて不規 則烦集して不鮮明となり，個々の細線維を識別するこ とは囷難であつた。

（5）その他の細胞質内諸斠造

A. 正常像に見られたものと同様に，円形乃至棈円形 の均質無構造の電子密度大なる小体が細胫質内に散在す るが，これらの增加あるいは減少を認めない，又，特に この群に特有な顆粒は見られなかつた。

B. 正常像に見られたものと全く同様の小空肥状檴造 が観察されるが，本構造の大きさ，部位，形状，增減な どについては明らかな变化がない。

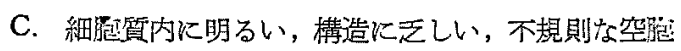
形成を認めるものがある.その一部では巨大な空胞が蜂

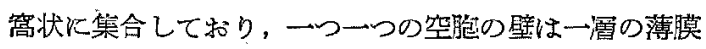
によつて限界されている.このような変化は一般に細脆: 質の辺縁に集合し，核の周辺江坬立性に存在することは ない，井上 28) は本操作を加えたもルモットの上頸節を 光学頭微鏡で観察し，空腿変性を認めたが，この空脆沉 一致するものと思われる。

(6) 細 胞 膜

低倍率にてすでに神経細腿と外套細脱の境界の不焦明 化が見られるが，高倍率を以つてしても細朖朕を判別す ることが不能であるが，一部では明らかに，両者の細胞 膜ととの間の細胞間隚を認める。

(7) 核

核の輸噺は美しい滑らかな円形を呈するものは一つも 見られず，その程度に多少の差はあるが一般に变形が著 明で，必ずしも細胞の变形や細胞質内の諸構造の变化と は平行せず，大小区ふの波状を呈するもの，圣全く不規 則なアメーパー状のもの等様々である。これらは常に核 膜により細胞質と画然と区別され，核貿が細胞質内に溶

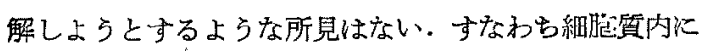

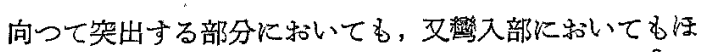
ら平行に走る二重膜を明膫に認めその間腔は約 $200 \AA ̊ 丿$ 测定され，異常な拡大は見られず，又明るく無構造であ る. 又内側膜は外儧膜に比して正常の場合と同様徨が
厚く、これらの模膜はいずれもその両面が滑沢で顆粒の 附着がない，Hartmann ${ }^{00}$ は神経線維切断後に起る舌 下神経核の神経細胞で，核膜の二重情造が早期に失われ ることを指摘した・文核の輸廓についてい言及していな いが，(氏の第 1 図和よび第 2 図)によると，核の变形は 見られず，私の所見と著しく異る. Barton とCausey 2) は, やはり神経線維切断後に起る神経細脆の变化を家鬼 の上頸節について観察したが，核膜については言及して 特らず明らかでないが，切断後 48 時間で核の波状変形 (convolution) の起ることを指㒀しており，私の前見と 類似する.

(8) 核仁

核仁の輸廟ははد゚形のものもあるが, 著しい変形を 示すものもかなり観察される。この場合必ずしも核の变 形の程度とは平行せず核は軽度の歪形を示すのに，核仁 は著しい変形を認めるものがある。しかし核仁の変形が いかに著しいものでも，全体としてまとまつた一個の微 細顆粒集合体をなし，ばらばらに分散するものはない， 穃仁の大きさ憎大の傾向を示しその直径が，核の直径 の1/2〜1/3に及ぶのもありこの点については考察に おいて後述したいただ本隋によれば，クロマトリーぜ に際して核仁が大となり核の辺緑又は核膜に接着するこ とが多いといら．私の所見ではクロマトンーゼの無い正

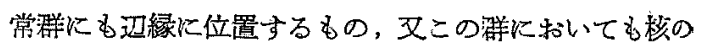
ほડ゙中央を占めるものも多く，必ずしも一定しない

核仁の搆造汇見られる変化は特異で，泌に集合する凯 細顆粒によつて極めて高い電子密度を呈する核仁糸が，

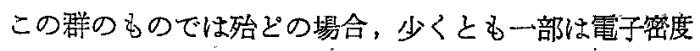
を減じて核仁系が著明に太く，これに伴つてこ〉に分布 する微細顆粒も粗となる。これは㭘も固く捻つた麻組か 次第にゆるんで，ほぐれつ」ある様に似ている．この变 化に伴い，必然的に核仁糸と核仁糸をの間の網腿は狭め られて小さくなりあるいは全く網眼の認められない部 分もあり, 前記の正常像に括ける核仁の第二の構造とし て述べたるのと全く同様の所見を呈する。特に著しい場 合には一個の核仁全体が活ら゙均等に分布する微細顆粒の 篗合体で，核仁糸や網腿を全く認めることができず，そ の一部では核質に向って次第に電子密度を減じて核仁と 榕質之の境界の不明瞭なものもあり，又あるものでは， 罢密な校仁光之不正形塊状物とが害然直接している。の むあり，一個の核仁が，常に全体として一様に変化する とは限らず，核仁の一部にのみこのような形態の变化を 認めるるのが多い，黑住と秋山 ${ }^{33)}$ は家鬼卵宩の卵脱上 


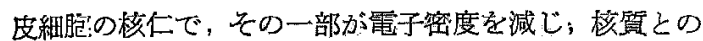
境界が不眼瞭なものを羡め，Horstmann 之 Knoop 22)

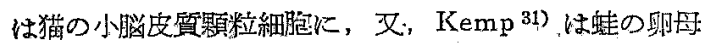
細膹に唡同様の所見を示している。しかしこれらは少く とも一部が告の主体がら島状に分離して存在するが; 私 の所見ではいす゚れる核仁が全体としてまとまつた形を 呈交省.

(9) 神, 経線 維

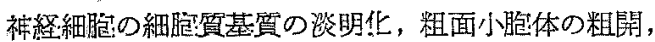

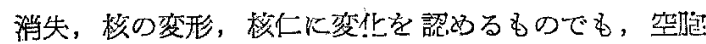
形成のないものでは，その近傍を走る神経䠔維己 Schwann 氏細脆泛の関係恬，正常の場合と变りがないが， 時として細脘の境界が不鮮明な部分では，やはり神経線 維を包孔二電の限界膜も不明瞙である。しかしこれに隣 接する神経線熦の限界膜が眀瞭なことるあるので，切片 の切れ力による相違を否定することはできない。この場

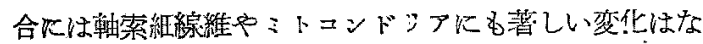
い，一方神経細胞に箸しい空䏸形成を認めるものでは， その附近の神経線維の内部構造に強い変化が見られ，明 るい無構造の部分と，顆粒状の凝集を思わせる不規則な 集塊之が混然とするが，これらは僌溹細線維や粗面小㴔 体が凝集したものであらう。

\section{第 IV 章 考察}

電子顥微鏡下に，このような実験に私ける細胞内の超 微細構造を観察しこれを考察することは誠に與味ある問

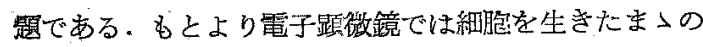
状態で，又一個の組胞を全体として把握することができ ず，試制作製に多くの過程を経た上，極好て薄い切片に 和ける所見であり, 細胞内諸器官の檑々の相互関係を知 るには不充分である。そこでっきるだけ正確に同一の条

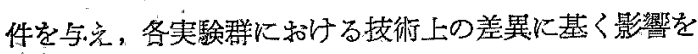
最小限にするよう努めた. 㱜後変化と固定時の人工産物 については，な特くの義論があるが，私は特に超薄切 片作㱔時に，包埋された組綵片の表層から約 $50 \mu$ 削り

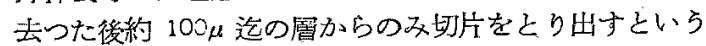
方法をとつた，その理由は後述の如く約 $0.5 \mathrm{~mm}^{3}$ 程度に 細切した組織片でも，種々の梁导の笛から観察される像 に多少の相異があり，澡贋程著しい人工産物を認めるこ とが判つたからである。

今日，交感神経細胞の変化を電子顕徽鏡的に追究した 韩告は，前述の Barton と Causey によるむのつみで あるが，その写真を見るとかなり厚い切片と思われ，正 常䣸についてすら私の所見と著しく異る。
他方，光学顕徽鏡に上る矿究については，自律神経

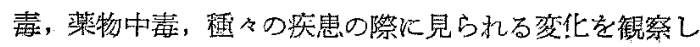

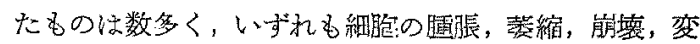
性,タェマ:シーゼ, 核の変形が举げら机ている。

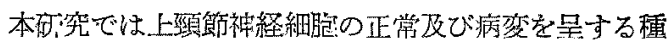
々の超微細構造を観察したが，その非，特に明らかな変 化を示した粗面小胞体，核及び稀仁に注目して猪察し動 物実験の意義に関しふれて㫕たい: ミトコンドシアにつ いては，Barton と Causey が家鬼の上頸節で神経線維 切断後7日目に:トニンドシアが空胿化し，破㯖され， 14日目に再び出現するとい〉，Hartmann はンッテの

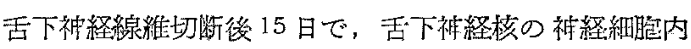
に異常に增加する微細顆粒が，ミトニンドッアであるこ

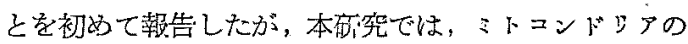
生成課程を思わせる像はなく，マトコンドンケの数はあ る程度の增加を示すものもあり，却って減少するものも ありー様でなからた。

第1 節 数面小捾体について

Pease $\angle$ Baker ${ }^{55)}$, Hartmann ${ }^{19)}$ は神経細胞内K初

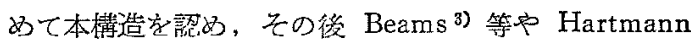
は，いくつがの細胞犋中に“フィラメントの束”焉

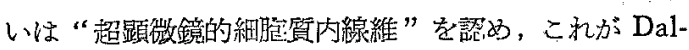
ton 12) B Bernhard 等 ${ }^{5}$ のいう肝や膵細㓐の細胞質内

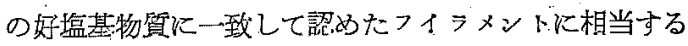
ものであると考えた。

今日ではかなり明瞭な概念が確立されて和り，Palade 53)は同一プロック上り得た神䋐細胞の電子顕微鏡像之 光学顕微鏡像を詨比して光学顕微鏡の標本で强い好塩基 性を示す ニッスル小体が，本棈造からなることを示し た. 又二ッスル小体については固定時に塊状に算集して 生じた人工産物であるか否かたりいて多くの占問があ り，最近では，König ${ }^{32)}$ 等は，䊿の Embryo の神経 細胞の紫外線像で生きた状態では見充ないが，ホルマり ン文はニッンールで固定したものでは凝集物が和㴔筫内 に認められ，これが固定による人工産物に他ならないと いち.一力 Deitch ${ }^{13)}$ らは鶏の替的道神経節細脆を生きた 状態と固定したものとを紫外線顕徽鏡下で対比観察し， ーッスル小体が人工産物でないことを示し，Brachet ${ }^{13)}$ 53）位相差像でニッスリ小体が生きた神経細胞中に存

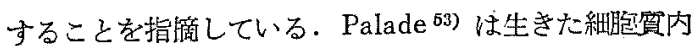
でびまん性に存在する物留が若し固定時沉沈澱あるいは 凝集によつて生じたものなら、ニッスル小体は当然紬胞 質内で再配分される訳で，その際電子顕微鏡的には，粗 
面小坨:体の規則的な配列や，微細精緻な形態をとらず， 収縮，断裂又は不規則な塊状物としての像を呈する筈で あるといらが，私むこれと意を同じらする。

上頸節神経細腿で 観察された粗面小腿体の構造は， Palade ${ }^{53)}$ が， 中枢及び末梢の種々の神経細䏲で観察し たものと基本的に一致している．たが黒住と秋山 ${ }^{34) ~ は ~}$

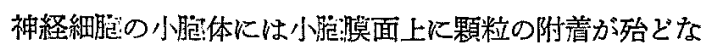
いことを指摘したが，私の所見でも既述の通り小腿膜 面上に顆粒を欠除するるのる少くなからた。 Bärton と Causey の上頸節神経細胞の電子频微鏡所見では，本構 造に言及していないがその写真では一般に語められてい る粗面小腿体得当する構造は見られない，

私はいくつかの稫本から，粗面小胞体の小胞腔の異常 な搪大と思和れる大小区々の管腔の不規則な配列を認め

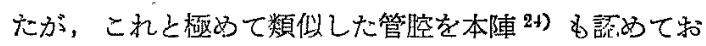
り，これを粗面小胞体あるいは滑面小䏯体と異る神経細 爸内の一種の管腔系を形成する trophospongium に一致 する構造と考支ている．花岡 23) は，位相差顕微鏡で形 質細胞の粗面小胞体を，超生体状態で観察し時間の経過 に伴ってこの部に明るい部分が次第に筓いて空胞を形成 していくのを指摘し，これを小胞体性空戺と乎んで招 り, 渡辺 ${ }^{77}$ ）は，粗面小脆体は本来細搃の生活状態や機 能に応じて連続的に形を变え得るものであるとい〉，與 味ある膜型を示している。これら小膇腔の桩大, 変形は 生理的な意義を持つものであろらが，一方人工的にも私 の認めたような異常な変形を何等かの作用によつて惹 起乙得るが，この場合小胞償は，部分的に不明膫で， 核質内の顆粒分布の不均等, 大小様々な塊状の部分之， 粗い網状をなす不規則な外観を伴い，又ミトコンドทと の構造も明らかでなく，しかもこの上らな不規則な搪大 した小䏲腔様の像は同一のブロッタでも表尿に近い部で は全く認められず，組緆片の中心に近い程，多数でしか も，すべての細脆内に一樣に認めることから，固定時に オスミウム酸が渗透していく時間的な差暴が一つの因子 となつて，試料作製過程に人工産物として表現されたす のと思われる。

本実験の長時間群では著しく粗面小胞体及びこつに密 集する微細顆粒の減少，消失を見たが，消失啳細胞内で いかなる形化变化するかは不明で，少くともとのよらな 像を認めなかつた，圣減少と同時に柾開の傾问を示す が、このことが，塊状をなすニッスル小体と細胞質基質 との境界を一䁲不明瞭化している。このよらな形態的变 化とその機能との相関々俰は明らかでなく，生化学的あ
るいは細胞化学的な分析を侯たねばならず，更に短時間 毎に時間を追つて検索することも必要であるう。

し沫し今日一般に細胞質中の好塩基物質は RNA の 存在を示するのと考克られ，㔻白合成の極めて盛九な腺 細脦に多量の好塩基物質蛋め，これが Palade の顆粒 及び粗面小胞体からなることから，神経細胞の粗面小胞 体の減少，消失は，好塩基物質の減少消失を意沬するも のであり，蛋白合成に大きな影響を与兄ていることは陮

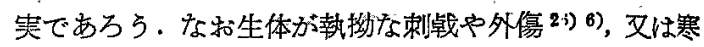
さ41)の上うな全身的ス:レスに曝される時，神経細胞 にクロマトシーゼが起ることが報告されているが，この 点本荚験の所見と一致する。

第 2節 校について

一般に核膜が二重償の構造を有し，㕛多数の核模孔を 倩えていることは，電子影微鏡によつて初めて見出され 種々の細胞について磪讃されている。すなわち核膜はは よ゙平行に走る内外二噌の脱とその間の幅約 $200 \AA$ の間腔 からなりこの三つの層を貫通する核膜孔が所々にあ る.

Anderson と Beams 1) は核脱孔を通して核質上細脆 質とを運絡する暗い物質を䛱め，この小孔から物質が移 動している像であるとしている、悡の認めた核膜孔は核 質と細脆算の直接するものと，一枚の薄い墕で閉ざされ ているものとを認めたが，有形成分の移動を思わせる上 らな像は胃られなかつた．この他に桹仁物質が，細胞質 に向つて笑出する外側核脱によつて生ずる拡大された核 裳腔内一昍き出され，細胞質への移動を思わせる所見む

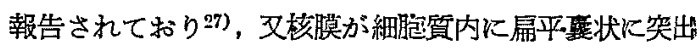
していることがあり，私の場合これが明らが小胞体们 連絡しているむのはなかつた、 Palade 50), 渡边77), Watson ${ }^{76)}$ ら江直接小脃体に連絡するものがあるとい, 渡辺 ${ }^{77)}$ は小胞体が校膜から形成されるるのと考觉， Palade 59）は核償は粗面小胞体の一形態であると考穴て いる.

さて神経細朌の核については,さきにられたHartmann が舌下神経切断後の同神経核神経細坨の核膜に微細な顆 䊀が多量に附著し, 二重椿造が失われるとい〉, 同時に 校質内の微細顆粒の減少を挙げ核質と細脃質とが核膜を 介して物質交換を行う可能性を想像している.Bartonと Causey 2) の神経線維切断後の上頸節神経細胞では 48 時 間後に核の輸廓の变形を示し又細胞質之核質と同様電子 密度が大となつて，両者のニントラストが低下するとい ろが,核膜については言及していない、私の実験では長時 
間群には核の波状変形が著明で，同時に核仁にも変化が 見られるが，核膜の二冓構造は完全に保たれて括り， $\mathrm{Ha}$ rtmann の所見とは異る. 氏の実験は神経缐維切断とい 万神経細造にとつてかなり强度の傷害であり，本実験で は恐らくそれょりあ軽度の持続的な傷害であうらから， このための相違と考皇ることもできる、文、亦化が必ずし も一様でなく；ある細胞ではクロマトリーゼが軽度であ るが，隣妾する別の細胞では高度であつたり，核の変形 中空胞形成を認める．しかし核の变形がかなり高度であ つても核膜二重棈造は破萝ざれて扣らず，これは Hartmann 26 ) の実験で核が 美しい円形を保ら乍ら二重膜構 造が失かれ，この部に多数の微細顆粒が集合する所見と は異るが，これもその時間的経過や，部位的差異によつ て必ずしも一様に起るとも考克られず，単純に比垔云々 することは難しい，文一つに注彼のこの研究当時には， 超薄切片の技術が未発達であり，かなり厚い切片での観 察であるように見受けられる，従つて切片が核の中心に 近い部分を切つたものでない限り，容易に幾何学的な厚 み効果により二重模は不鮮明化したように見える訳であ る.しかし神経細胞:の核膜も又, 核質と細胞質の閒の穔 極的な仲立らを果すであろうことは考えられる。

核の波状变形の著明なものでは，乙ばしば核の笑出部

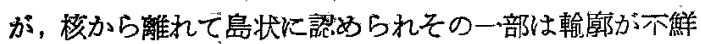
明であるが，このことから，このような变形が立体的に は金米糖状を呈するもの上考克られ，これが膨化を意味 するものであろらか，あるいは細脃質と接触面を增大せ んとする变形なのか，又核に加わる的力，例えば核と細 胞質之の渗透圧の差に基く濃綰像かなどという問題が今 後追究されるべきであろう.

核質は全体に微細顆粒が均等に充満しており，各群の 間には特にこれら分有の上に変化を見出せず，染色綪 造に相当する所見は明らかでなかった。

元来電子顕微鏡賩本は極く薄いことが要求され，この ため，物の大小を簡単に比較することは危険であり，切 れ方による影既について慎重でなければならない，又電 子密度の大小から核の濃縮，膨化を云々するのも誤りを 招き易い，之れ切片の厚さに比例して電子密度が大と なるからで，切片の厚さを実際に測定することは現在の ところ不可能だからである. 従つて常にこれらの点に注 意を払わなければならないと考える。

第3 節 核仁について

一般に核仁の微細棈造に関しては，最近まで余り知 られておらず，光学顕微鏡下に，Estable と Sotelo ${ }^{1 \hbar)}$
（1951）が，網状にからみ会つた線維構造之無構造の不 定形物質茂，恒久的構造成 々分として存することを指 摘し，前者を Nucleolonema（核仁糸），後者を Pars amorpha 々呼えだ。そ後電子顕微鏡が，生物の形態 学の分野に取大れられるや，これらの存在が更に確か 子ちられ, Borysko と Bang 7) (1952). Berhard 等 4) (1955), Kemp 31) (1956), Horstmatin \& Knoop 2:)

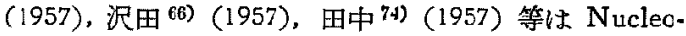
lonema 及び Pars amorpha を雷子㩆微鏡下に観察し た. 黑住 33) (1958) は更に数種の細腿の䅭仁を锤察し, Nucleolonema, Pars sphaeroidea の他に Pars amorpha と呼称すべき構造のあることを指摘した。これを要 約すれば，現在核仁の構造はいずれる同一の大きさを有 する微細顆粒の 集合体であつて，その集合の仕方によ り,

$\begin{array}{ll}\text { Nucleolonema } & \text { 䋑状構造 } \\ \text { Pars amorpha } & \text { 不定形塊状体 } \\ \text { Pars sphaeroidea } & \text { 大小の球状体 }\end{array}$

の三つの翌に分けられこれらはいずれも同一の電子密 度を有し，一個の核仁がこの中の二程以上の構造からな る場合と、たが一䡒のみからなることがあるといわれ る。

Barton 上 Causey 2) (1958) の家束上頸節神経細胞 の矿究では，核仁には言及していないが， plate 2-No。 6 は Nucleolonema のみからなり，plate 4-No.11は， Nucleolonema と電子密度小なる不定形塊状体とから なるがこれは Nucleolonema に比し明らかに電子泌 度が小である点, 上述の Pars amorpha とは異るもの であうう、しかもこの塊状体は私の諗沐たものと極めて 類似している。

沢田 ${ }^{63)}$ (1957) は二十日開の精母細胞の核小体がやは り Nucleolonema と，先机密接する球状体からなる とい〉, その球状体は, Nucleolonema に比乙, 電子泌 度が低いことを示している。

Fawcett ${ }^{17)}$ (1956)は，ザリガ=の精子細胞分裂前期 汇核仁の一部が核質に移行する像を示し，Horstmann と Knoop ${ }^{229)}$ は猫の小脳皮質の顆粒細胞の核仁が，Nucleolonema からなるが，一部では電子密度を減じて核 資との境界が，不明瞭なるのを認め，核仁を構成する物

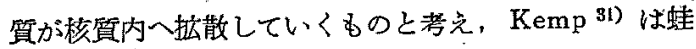
の卵母細胞でも同様の前見を認めているが，黒住 ${ }^{33)} は$ Nucleolonema が斜に切れて，その周辺部をかすめて妡 つた場合か電子密度の渐减によって，一部が不明膫に見 


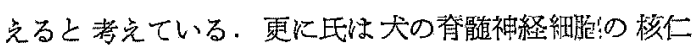
が, Nucleolonema の殁からり，Pars amorpha に相 当するものは認ぬないという。

私の所見では，既迹の如く，長時間群行見られた核仁

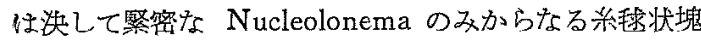
ではなく、むしろこれよりす電子㗪度の低い単に不正形 塊状に集合した顆粒よりなるか，又は Nucleolonema からなる系球塊がゆるんで，全体として艺の大きさが增 大し, Nucleolonema そのむのも太くなつて電子密度を 減じ, Nucleolonema によつて作られる密網の間の網眼 が狭小であるものが纴倒的に多いことを秘認し，更にあ るものでは緊密な Nucleolonema と不定形塊状の粗な る微細顆粒集合休とが立体的に抱き会ら上らに接着して いるのではないかと考壳られるすのもあり，一個の核仁 が，必ずしも全体として一様化变化するとは限らず，核 ヒの一部にのみこの上らな形態の変化を認めるものもあ る.これらはしばしば，正常の神経紐胞にも認められ， 特に核仁が栐膜に接着する部分では必ずこのように粗な 微細顆粒集合体として観察される，この点切片の切れ力 による電子密度の漸減とする考え方たけでは，充分に説 明し得ないのではなかるらか。

それでは，電子密度小な部分すなわら凯細顒粒の粗に 集合した部分とはいかなるものであううか. Kaufmann 30) は核仁の中にクロマチン顆粒を見出し，又 Irene Coy ${ }^{30)}$ 性核仁中の小空胞吕， Feulgen 隆性を示して 後陽性の段階を示すとい〉, Milard ${ }^{30)}$ む核仁内部に Feulgen 陽性の顆粒の存することを指摘しているが， これらは Casperson8) のいら Nucleolus-associatedchromatin に一致するすので方り, 又 Hert1 ${ }^{21}$ は染色 反応户細胞化学的检查の上で，クロマチンに極似の態度 安示す perinucleoläres Körperchen の種々相を模型図 に示しているが，この構造に相当するるのかも知れな い，しかりとすれば，電子顕微鏡下飞観察される電子密 度小なる Pars amorpha と大なる Pars amorpha とは 異質のるのということになる。しかし現在の前，電子密 度小なる Pars amorpha perinucleoläres Körperchen と同定することは困難であり，少くとも電子㩆微

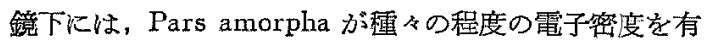
すること以外には，明らかな差異を認めることができ す゚，しかもこの雪子密度の大小性 Nucleolonema との 比較に执いていえるので，絶対的なるのでなく同一の核 仁に特いてその Nucleolonema 自体にも電子泌度にか なりの差異が認められることから私は，本上頸節神経細
胞の核仁が，

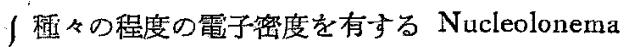

【䄸々の程度の電子密度を有する Pars amorpha の組合好又はたら゙一つの構成要素からなり，生理的乃至 病理的な生活熊状や機能に応じて核仁の一部》は全体沉 種々の形態的な变化々電子密度の変化を示すものと考察 する. 更にこれに伴つて細起化学的な組成の変化が起つ ているのではなかららか。

な特，この電子密度の小なる塊状体や Nucleolonema， すなわ方微細顆粒が粗に集合した部分には，所ねに径約 30 $\mathrm{m} \mu$ の湢を有する練棌状の像を認めた。これは三層か らなり, 比較的電子密度の小なる圆を挾んで, 密集した 顆粒状を示方外層が注が平行に走るが，これらを一つの 構造と見做し得るか否かといてはな和茄究の余地があ

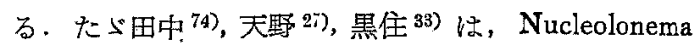
が，その軸に対して，斜に配列する微細顆粒の縞模様を 有することから更に低次のらせん糸より構成ざ礼ると述 ベ，又黒住と秋山、3) がこれを primary Nucleolonema

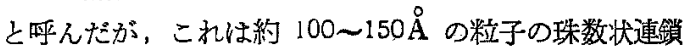
からなるといら．従つて私の認めたものと構造及び大き さが異る。

核仁の㙨能については, Casperson (1950)93. が核仁 には RNA を多量に含みとの周辺に DNA が附着して 特り, 核仁の RNA 蛋白は正常な細胞火和いて, 核仁 から核腽へ向つて掋散し核膜の外側で盛九な蛋白合成を 行らとい〉, 少くとも今日では核中の RNA が主に仁 にあるといらことは一般譛められて扣り，その件梁色 貿や染色体中炕も RNA があるらしいことが判つてい たが，RNA については，DNA の証明に和ける Feul。 gen 反応の上うな特有の民応がなく，染色質中染色体中 の RNAを检出することは困難であつた。しかし，Mc Master-Kaye と Taylor 40)（1958）に上り超遠门分離 器や放射性同位元素 $\mathrm{C}^{14}$ の化合物を使つた矽究がら，核 には少くとも二種の RNA があり，そのらち一つは仁 火，他は染色質又は染色体の部分にあり，年の塩基組成 が多少異つていて，核仁の RNA は染色質のそ礼に比 し，はるかに代謝回転は高く，練胞質の RNA，比し 核の RNA が代謝回較の早いのはこのためである方と い5. 又 Stich ${ }^{65)}$ は仁が，染色体の遺伝的機能炕利用 される蛋白質の合成に与かることを述でている・いずれ にしても，生化学的に核仁が， RNA を含む虽白からな ることは明らかであるが，電子顕微鏡的には; Porter ${ }^{57)}$ （1954）が核仁を構成する小顆粒が大きさの点で Palade 
の顆粒とよく一致することから，これが RNA からな るものと想像している。

又核仁の機能が形態の上にいが表現されるは現在の 所、明らかでないが，これを暗示する所見として次のよ らな報告がある。

Lettré ${ }^{20)}$ は線維細胞の組織培着時に adenosine を加 えると，校仁が核膜に向つて移動し，Pars amorpha を 核膜外飞继出して，Nuclolonema だけが，核膜の中に 残ることを，位相差顕徽鏡で示し，この時の Nucleolonema は Feulgen 陽性の性状を示すという. 勿諭この 場合 Pars amorpha が，果して電子顕微鏡での Pars amorpha と全く同一のものかどらかは疑問であるう.

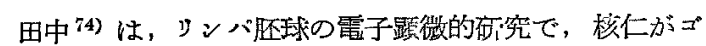
ルヂ体側に接してくると，その部の外側核膜が細脉質に 向つて突出し，やがてその乫出腔へ仁物質が流出してい くといい，これは若い細㛬の核と細脂滇との交通の一様 式であると考えている。黑住 ${ }^{33)}$ は家鬼の卵栄間質細㬶: でしばしば，核仁の核が辺緑に位置し，Nucleolonema が伸びて，々の一端が核仁の内面に接着する像を認めて いるが，核仁構成物質と同様な 電子密度を有寸るもの が，核膜を通して外へ流出する像は䜅めなからたとい

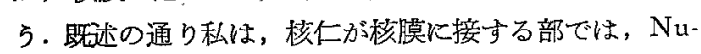
cleolonema が增大して電子密度を減ずること，しばし ばこれが，電子滵度小なる不定形の集塊として観察され

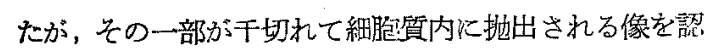
めなからたこの外にも，核仁物質が艺のま〉，細脆濽 内の RNA 顆粒と直接関保を持つという報告に接して いない。

このように生化学的に核仁と RNA 蛋白との関係が， ある程度まで明らかとなり，形態学的には細胞の機能の 推移に伴つて核仁が種々の変化を示すことが判つてき た. 徉つて細脆が活發に分化あるいは增殖を営む際には 当然, 細脃質中の RNA, 染色質中の RNA, 核仁中の RNA が主要な役割を果し，これらの間には相関々倸が 考えられるから，分化あるいは増殖の旺盛な卵細脆き腷 瘍紏胞について，その核仁の形態を把㩧していくこと は，興味ある問題であるう，本実験の長時間群に出ける 病理的な状態吙いて，粗面小胞体とこ〉に密集する RNA 顆粒の踈開，減少，消失と同時に核仁に見られる このような像も，将来はこの観点から换討を加えら水な けれぱならない。

第 4 節 動物実験沉ついて

本動物実駼は当教室の飯田 ${ }^{29}$ ，深沢 ${ }^{25)}$ により Spe- ransky 64) の用いた方法を応用して考案されたるので， クロトン油の過剩刺㦸により䓺起されると考它られるシ ョッタ症状が，特に口唇及び口蓋部に局所的特異性を有 するものであり，その病変が内茈諸者藏器の血管等を主体 とした充らつ血，浮国，出血，時に変性，填死等の病理 細䋨所見を呈し，これがレイッー氏現象の所見 ${ }^{79}$ 之類 似する点を指摘し，適量のクロールプロマジンにより,シ ョックおよでこれらの病変が阻止されることを示した。 クロールプロマジンの作用機字については現在の所, 必 ずしも明らかでないが，主として植物神経系（特に交感

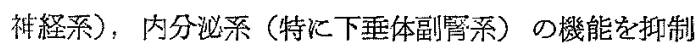
乙て全身の代謝低下を抬来的他, 中枢鎮静作用, 制 吐作用，括上び抗痤㢣作用が一般に知られて括り，こ れらの点からこの実験に和ける植物神経系の関与を示 崚した.

本研究で上頸部交感神経節を撰えだのは, 解剖学的に これが口唇及び口蓋と密接な関係を有するからであり，

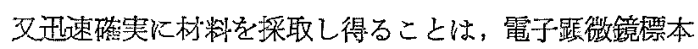
作製に最る適するものである。

J. Reillyは1934 年, 锁最のチフス菌毒素を晹間膜リ ン八腙内に注射して腸壁に病変を作り，こ小に分布する 神経線維との接触に上り内葴神経を介して腸壁に病変を 作るもの之考劣, 植物神経とりンバ采, 絧内杀, 内分泌 系との緊密た関係を指摘した. その後多くの議論と研究 を生み, Marquézy, Ladet, Gauthier-Villors ${ }^{29)}$ (1935)

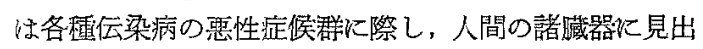
される病変が，Reilly 等の植物神経を傷害して若起した 変化似ていることを認め，Gregoire et Couvelaire

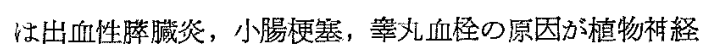
の障觜によるものと考光た。我が国では白石 ${ }^{67}$ ) 等が实

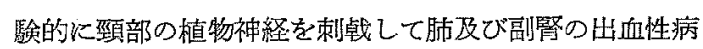

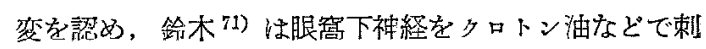
战し内臓々器に出血性病变を作り，いずれるクロールブ ロマジンにより阻止し得たとい」，五十嵐 ${ }^{22)}$ は頸静脈 㢣胞内に起腎炎株培盖滤液を注入して一過性の臂炎がお

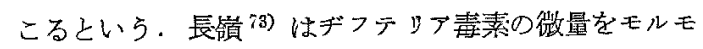

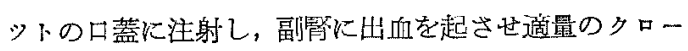
ルプロマジン投与により阻止し得ること，又下垂体全阙 出動物では出血を認めず，又土屋と秋庭 ${ }^{55)}$ は電気的及 び化学的に内藏神経を刺㛺して急性出血性膵葴炎を作 り，適量のタロールプロマジン投与，下垂体又は副管の 腐出により阻止され，間媨一下垂体一副简系の関与を指

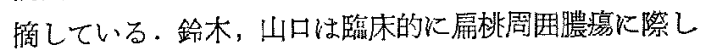




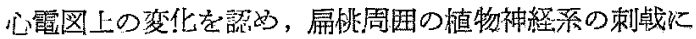
よるものと考克，飞の他クロールプロマジンによるショ ックの臨床治験例も少くない7(1) 81)，解剖学的には，永

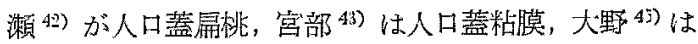
モルモッ:の口唇及び口蓋を検索し，これらの部に比较

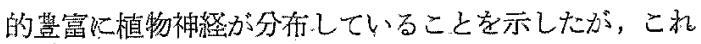

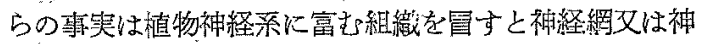

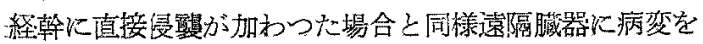
起すといら Reilly の考乬関連を有するものと思われ

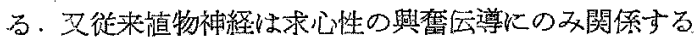
ものと考方られていたが，沖中41 は求心性の经尊の役 能果果すことを証明して和り，Mallet-Guy (8)は膵の慢 性炎应性刺㦸がこれを支配する内臟神経節に変化を和こ すことを認めている。

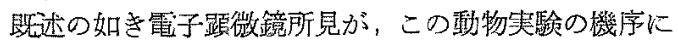
関士る一面を表慁したものであるとはいえ，現在の所

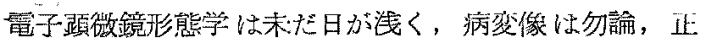

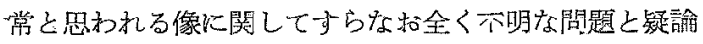
がありこれ家以つて多くを論ずることは危険を隹和難

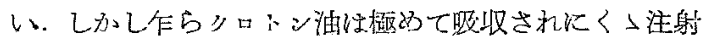

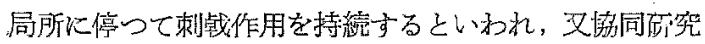

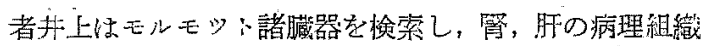
像が短時酒と長時間群の閻に㱠ど差がないという。しか

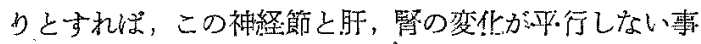

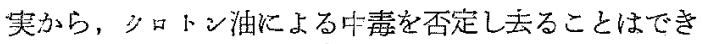

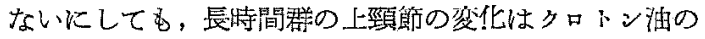
剌裁による薬理作用の华に，生体が恒常性を維持せえと するための反応との綜合結果と考えるべきであり，慢性 刺㦸に刘しこの上らな意珠:での植物神絽の関与が存在し 得ると思う，これは特にタロマトシーでが外傷656)や 全身的な寒玲 ${ }^{41}$ 等のストレスに祭し出現するといら報

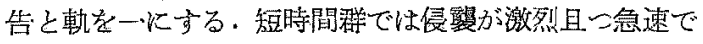
あるた犻粗物神絃一内分汹系の過剩な與奮にもとつく

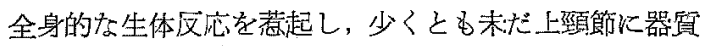

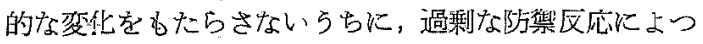
て遂に生体自身が疲僙し，失調に宿りシショッ症状を 呈したるのではなかららか，逆に植物神経系自体に早期

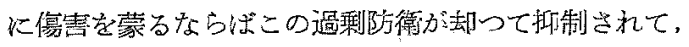
その榎害が軽度である限りは長時間策と同様に整死する ことなく生存し得たであるらことも考它られる、従つて 啫時間群が電子显微镜下に変化が明らかでない点からら， 上頸節の関与老否定す心゙でなく，嘰能的にはむしろ高 度の反応を示していたであるらことは推察に難くない
電子顕做鏡てよりこのよらな状態におかれた神経細胞の 形態学的な表現を把握し，元の相関々係を見出すことは

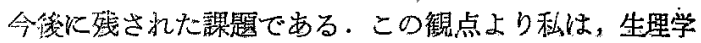
的及び生化学的方洗と相俟つて特にシナップスの追究が

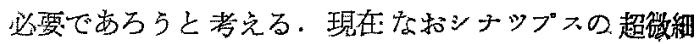

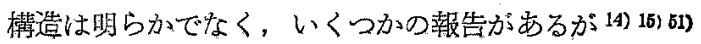
5.)，極く限られた神経終末で， synaptic vesicles の增 減や移動が與鹤伝遒に咸係があるであるらといれれる。

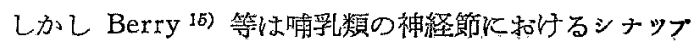

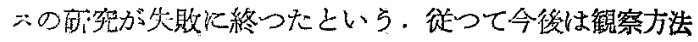
の技術的な進步発展と細腺の超顕微鏡的な諸構造の生物

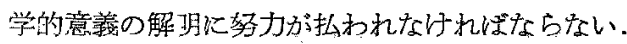

\section{第 V章 むす}

1. 実験的レーシー現象に括ける末松交感神経細胞の 関与を電子顕微镜下に追究する目的を以つて, 毕ず正常 なモルニットの上頸節神経細腿の超微細構造を明らか心 し，口唇より口盖にかけて粘膜下に微量のタロトン油を 注射してショックを起させた場合（短時間登）と稀秎し たタロトン油を反復して注射し，20日を経過したモル

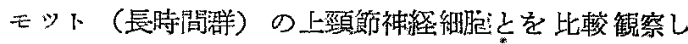
た.

2. 正常なニルニットの上頸節神経細胞のニッスル小 体に一致して見られる粗面小脂体は，規則正しい配列嵅 とるものから不規則なものむであるが，ての形は殆ど扁

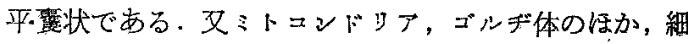

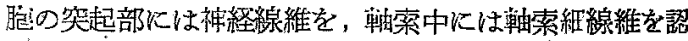
わた。細脂膜には一部に著明な切れ込み（infolding）が 存字宗。

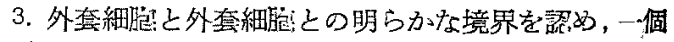

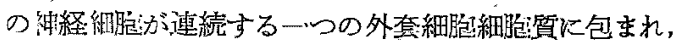

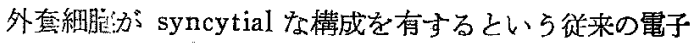
繁徽鏡所見を否定した。

4. 正常な上頸節神経細朖の核仁は, Nucleolonema の勿合する系逮状の小体ばかりでなく，一部がこれより む電子密度の小塊状体からなることを認が，特に核膜 に接着する部分は電子密度が小で Nucleolonema がた 明留である。

5. 光学顕微鏡下に核仁と区別される Nucleolus-associated-chromatin あるいは perinucleoläres Kör-

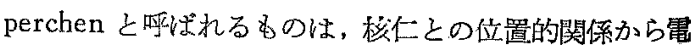
子密度小なる塊状体に類似するが，この耐者の間には明 らかな限界がなく，単に微細顆粒分布の粗な部分と密な 部分上かが次第に移行するか，又は突然直接する。 
6. 核仁の電子密度小なる部分に 細系状の像を認めた がこれを一種の構造と考え得るか否か，な科究の余 地がある。

7. 短時間洋に関しては，特に，正常群との間に明ら かな差異を見出すことができなかつた。こ机正常清の

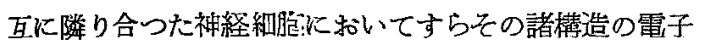
密度，分布，配列，大きさ，数等が，一樣でなく，变化 に富むことが，短時間洋に打ける反応の形態学的表現を 把握することを困難ならしめた．同時にこのことから正 常時の神経細朖肪個々に独目の生活状態中機能を発揮し ているすのと考える。

8. 長時間群では粗面小胞体の蹯開と著明な減少，消 失が見られ，核は波状の変形が强いが，核荧二重溝造は よく保たれている。核仁は增大の傾向を示す之同時比 Nucleolonemaは太くなり，その網恨が狭少となつて。 一部では，核仁を構成する 微細糟柆の分布が 粗となつ て，核仁と秘質との限界が不明膫化する。

9. 種々のストレスに際し，クロマ:リーゼが出現す ることは光学顕微鏡に誌められているが，電子顕微鏡下 《は，粗面小犯体の踈開，減少，消失之して表現され る.同時に核の変形核仁の構造に現れた一連の変化は神

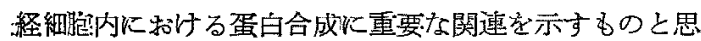
われ，長時間碓における慢性刺战が上頸節にこのよらな

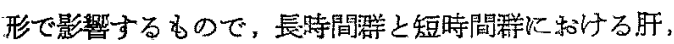
督の態度は上頸節と異り，差異のないことから，中毒を 全く否定し去ることはできないにしてる，生体の恒常性 維持の際の交感神経系の関与の一側面を表わするのと考 えるべきであろう，短時間群では，過剩防衛に与かる上 頸節が少くとも末だ電子頙微鏡形態学的变化を示寸以前 の機能的，可逆的な反応状態にあつて，この反応が激 烈，且つ急速に進罱して神経細胞!自身に变化をきたさな いことが，一軍この反応を促して本刺皒が致命的効果を゙ 発揮するもの之解釈する。

\section{参考文献}

1) Anderson, E. and Beams, H.W.: J. Biophys. Bio chem. Catol., 2 suppl., 439, $1956 . \quad$ 2) Barton, $A$. A. \& Causey, G.: J. Anat., 92, 399, 1958. Beams. H.W., van Breeman, V.L., Newfang, D.M., and Evans, T.C.: J. Comp. Neurol., 96, 249, 1952. 4) Bernhard, W., Haguenau, F., Gauthier, A. and Oberling, Ch.: Z. Zellforsch.s 37, 281, 1952.

Bernhard, W., F. Haguenau et Ch. Oberling: Experientia, 8, 58, 1952. .6) Bodian, D., and Mellors,
R.C.: Exp. Med., 81, 469, 1945. 7) Borysko, $E$. and F.B. Bang: J. Appl. Physics, 23, 163, 1952. 8) Casperson, T.O.: Symp. Soc. Exp. Biol., 10, 127, 1947. 9) Casperson, T.O.: "Cell Growth and Cell Function." E.E. Norton \& Co. N.Y. 1950, 10) Causey, G. \& Hoffmann, H.: Brit. J. Cancer, 9, 660, 1955. 11) Cansey, G. \& Hoffmann, H.: J. Anat., 90, 1, 1956.12 12) Dalton, A.J.: Am. J. Anat., 89, 109, 1951. 13) Deitch, A.D., and Mosses M.J.: J. Biophys. Biochem. Cytol., 3, 449, 1957. 14) De Robertis, E. and Bennet, H.S.: J. Biophys. Biochem. Cytol., 1, 47, 1955. 15) De Robertis, E. and Vaz Ferriera, A.: ibid 3, 611, 1957. Estable, C. y Solelo, J.R.: From "Fine Structure of Cells" International Union of Biological Sciences Series B, 21, 1954.117$)$ Fawcett, D.W. and Burgos M.H.: Anat. Rec. 124, 401, 1956. Gasser, H.S.: Cold Spr. Harb. Symp. quant. Biol., 17, 32, 1952. (from Causey, G. \& Hoffmann, H. 1955). 19) Hartmann, J.F.. J. Comp. Neurol., 99, 201, 1953. 20) Hartmann, J. F.: Anat. Rec., 118, 19, 1954. 21) Hertl, U.: Z. Zellforsch. 46, 18, 1957. 22) Horstmann, E. und Knoop, A.; Z. Zellforsch. 46, 100, 1957.23$)$ 花岡正男: 日血会 誌, 19, 341, 1956. 24) 本陣良平: 綜合医学, 14,

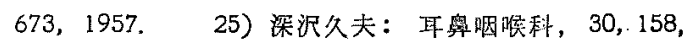
1958. 26) Hydén, H.: Acta Physiol. scand., 6, Suppl., 17, 1, 1943. 27) 伊豆律, 天野: 最新医学, 12,2295，1957.28）并上泰樹：“モルモット口唇刺

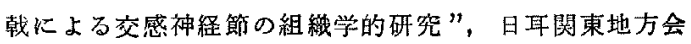
第 36 回大会, 昭和 34 年 4 月。2 29）飯田稳：耳奥咽 㞺科, 30, 158, 1958. 30) Kaufmann, B.: Z. Zellforsch., 28, 1, 1938 . 31) Kemp, N.E.. J. Biophys, Biochem. Cytol., 2, 281, 1956. 32) Koenig, H. and Feldman, D.,; J. Histochem. and Cytochem. 2, 334, 1954. 33) 黑住, 秋山：日本組織学記録，14，291, 1958. 34) 黑住, 秋山: 第 15 回電頭学会予铜集, 60,1959 . 35) 哭, 沖中：自律种経系䋓諭, 改宁第 6 版，金原出版，昭和 31 年 6 月. 36) Laboril, H.: Réaction organique à l'Agression et choc, 1955. (侵

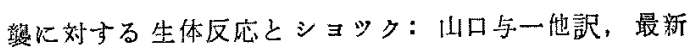
医学社). 37) Lettré, R.: “Fine Structure of Cells" International Union of Biological Sciences 
Series B, 21, 141, 1955.

38) Mallet-Guiy: Pancreatitis Chroniques Gauches masson Ed., Paris, 1943. 39) Marquézy, R.A., Ladet, M. et P. Gauthier.Villars; Soc. med. Hôpit. de Paris, mai 1938. 40) McMaster.Kaye, R., \& J.H. Taylor; J. Biophys. Biochem. Cytol., 4, 5, 1958.

41) Nurnberger, J.I.: Research Publ. Ass. Research in Nerv. and Ment. Dis., 32, 132, 1953.42$)$ 水瀬邦彦：日 耳会報，61(9)，1480，1958.43）西端(眑), 宮部, 倉井他：“人口蓋粘膜 及び下甲介阽膜の 神経分布につ いて”，日耳第60 会緼会，昭和 34 年3月. 44) 沖 中重雄：生体の科学，1，35，1948，45）大野交期： “モルモットロ溘の神経分布について”、日耳関東地方会 第36回大会, 炤和 34 年 4 月. 46) Palade，G.E.: J. Exp. Med., 95, 285, 1952. 47) Palade, G.E.: Anat. Rec., 114, 427, 1952 . 48) Palade, G.E.: J. Histochem. and Cytochem., 1, 188, 1953.49$) \mathrm{Pa}$ Iade, G.E.: J. Biochem. Cytol., 2, suppl, 85, 1956. 50) Palade, G.E.: J. Biophys. Biochem. Cytol., 1, 567, 1955.51$)$ Palade, G.E.: Anat. Rec., 118, 335, 1954. 52) Palay, S.L.: Anat. Rec., 118, 336, 1954. 53) Palay, S.L. and Palade, G.E.: J. Bio. physic. Biochem. Cytology, 1, 69, 1955. 54) Palay, S.L. and Wissig, S.L.: Anat. Rec., 116, 301, 1953. 55) Pease, D. and Baker, R.F.: Anat. Rec., 110 , 505, 1951 56) Pfitzner, W.: Arch. mik. Anat., 22, 616, 1883. 57) Porter, K.R.: J. Histochem. and Cytochem. 2, 346, 1954. 58) Selye, H.: 適 応症候群, 田多井吉之助訳, 医蔽薬出版, 昭和 27 年. 59) Selye, H.: Text-book of Endocrinology ( 工新内分泌学, 田多井吉之助訳, 医落萝出版, 1947). 60) Sjöstrand, F.S.: Nature, 171, 30, 1953. Sjöstrand, F.S. and Rhodin, J.: Exp. Cell Res., 4, 426, 1953. 62) Sjöstrand, F.S.: J. Cell Comp. Physiol., 42, 15, $1953 . \quad$ 63) Sjöstrand, F.S.: ibid. 45, 1953, 64) Speransky, A.D.: A Basis for the theory of medicine, 1943. International Publishers Co. Inc. 65) Stich, H.: Experientia, 12, 7, 1956. 66) 沢田品：解剖誌，32，423，1957。67) 白井幸讨 郎他: 日本内分泌学雑読, $32(3), 156$, 昭和 31 年 6 月. 68）铃木安恒他：耳鼻咽喉科展望，2(2)，124，1959.

69）跲木安恒他：耳鼻咽喉科，30,153, 1958. 鈴木安恒他：耳奥咽喉科，30,774, 1958.

71) 鈴木
（安)，高崎，鈴木 (㤵) 他：“眼窝下神経過剩刺戙飞上 る三三臓器の变化”, 日开第 59 回総会, 昭和 33 年 4 月。

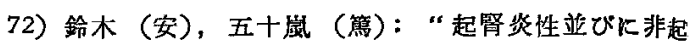

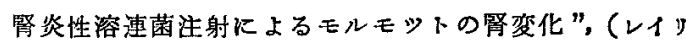
一氏現象の钼察)，日耳第 60 回総会，昭和 34 年 3 月. 73）鉿木（恒），長嶺：“急性感染症に掠ける自律神経 系の関与について”。第 3 報, 第 34 回伝染病学会, 昭 利34 年 4 月. 74) 田中春高：日血会誌，20，237， 1957.75) 土屋, 秋庭：日本内分泌学雅誌，32(10)， 110, 昭和 31 年 5 月. 76) Watson, M.L.: J, Biophys. Biochem. Cytol., 1, 257, 1955 . 77) 渡辺陽之 䡋：細胞化学シンボジウム，5，35，1956. 78）山口 与一：日仏医学，2，19，1955. 29）山口与一：最 新医学，10(2)，158，1955，80) 山口与一：最新医 学, $11,102,1956.81$ ) 山口与一: 噔応医学, 33, $213,1956$.

付図 1 (正常群 $\times 3,500$ )

一個の神経細胞とこれを囲む外套細胞を示す。 本神経細胞は，泟今゙円形の核 $(\mathrm{n}) 二$ 二個を有し，

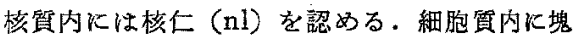
状をなす電子密度のや小大なるニッスル小体 (N)、ミトニシドリア（m）はこれよりむ電子 密度が大で顆粒状を呈する．左上方外套細胞 の核（nc）が二個荊えで見える，外套細胞と外 套細胞との境界（个）が明らかである。

付図 2 (正常群 $\times 30,000$ )

比較的よく配列した粗面小胞体 (ER)，こ入 微細顆粒が rosette 状に密集している。粗面小 胞体の膜面上飞镫細顆粒を欠除する部分方少く ない，下方にゴルデ体 (G)、ミトコンドリア （m）を認める.

付図 3 (正常群 $\times 25,000$ )

右上方が秆経細胞の核，左下方が細胞質，その 間を二重構造を有する核膜 ( $\mathrm{nm}$ ) が走る。左 上方滘同心丹状に配列した滑面小胞体 (W) 認める，右杵内はこの強挾大で，中心に顆粒状 の電子密度大なる物貿が䈎合する。趾胞筫内下 部はゴルデ野（G）によつて占められる．又滴 状小体 (d)，及び空胞状槽造 (V) を認ぬる.

付図 4 (正常群 $\times 27,000$ 及び $\times 60,000$ )

神経細胞突起部の横断面，上方の電子密度大な る部分は外套細胞の核 (nc)，中央汇粗面小胞 
体 (ER)，その下部に明らかな細胞間隙を有す るSchwann 氏細胞上神経細胞の細胞膜 $(\mathrm{cm})$ との境界が存する。枠内はミトコンドリアを強 扗大したもの.二重の限界㟰及び Cristae mitochondriales を認める。

付図 5 (正常群 $\times 3,800$ 及び $\times 13,500$ )

神経細胞と外套細胞との境界は一部では互いに 哭出，又は湾入した切れ込み（i）を示す 外套 細胞又は Schwann 氏細胞の細胞質内に包まれ る軸索（ax）内に，軸索細線維（af）が軸に平 行に束状又は錯雑した走行を示す. 枠内は神経 細胞の笑起部に見られる神絓細線維 (nf) を示 t

付図 6 (正常群 $\times 4,300$ )

神経細胞の核（n) は美しい円形を示す 核仁 は Nucleolonema からなる亲逮状塊 $\left(\mathrm{nl}_{1}\right)$ と, これより電子密度の小な塊状体 $\left(\mathrm{nl}_{2}\right)$ との二種 の構造が接しており，その間に境界構造は認め られない.

付図 7 (正常群 $\times 27,000$ )

右上方の大部分は核 (n)，核仁（nl）山緊密に 吻合する Nucleolonema（nla）の糸球状塊よ りなり，微細顆粒から構成される。核質内にも ほ心゙同樣の顆粒が粗に均等な分布を示し，核仁 （n1）との間には境界膜を認めない。

付図 8 (正常群 $\times 30,000$ )

Schwann 氏細胞の細胞質内走る無䯣神経線 維の横断像，すなわち䡛案 (ax) が Schwann 氏細胞の細胞質内に包み迅まれる時に生ずる結 合膜（mes）の長いるの，又ほとんど全くない

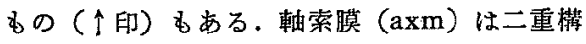
造を有する。

村図 9(短時間群 $\times 38,000)$

右方の大部分は神経細胞の細胞質，細胞留内に はミトコンドリア $(\mathrm{m})$ ，上方に限界膜を持たな い電子密度大な均質無構造の滴状小体 (d) 考認 める。核膜は明らかな二重膜構造を示し，所々 に核膜孔（个印）を有する，核仁（nl）の一部 注核膜に接着し Nucleolonema は不明瞭化し ている。

村図 10 (短時間群 $\times 30,000$ )

ほડ゙中央にゴルギ膜 $(\mathrm{Gm})$, エ゙ルデ空胞 $(\mathrm{Gv})$, ゴルデ顆粒（Gg）からなる層状排列のゴルデ
体，右方は波状の翰棜をなす神経勫胞の核 (n)， 細胞質内には複雑な配列を示す粗面小胞体 (ER) が存する。

付図 11 (長洔間群 $\times 22,000$ 及 $20 \times 6,900)$

長時間群では一般沈神経細胞の粗面小胞体 (ER') が眯開し，減少消失の傾向を示すものか; 多い，梏内は核 (n) の金米精状变形で一部代 はな怙状に集合する数面小胞体（ER）を認 める。

付図 12 (長時間群 $\times 14,000$ )

核の変形及び Chromatolyse を認める他, 核化 （nl）は異常に增大し，Nucleolonema とこれ よりも電子密度小な Pars amorpha からなる 部分を認め，この部にゆるやかな波状を呈し， 非上平行に走る細系状の像を認める。

付图 13 (長時間群 $\times 26,000$ )

增大せる神経細胞の核仁 (nI)，一部ではこっに 集合する微細顆粒の分布が粗となり，核質との 境界が不鮮明化している。(†印)右上方に外 蒦細胞の核の一部を゙見る。外套絓胞と神経細胞 との境界は一部では不明瞭であるが，これは切 片の切れ方によるものと思われる。

付図 14 長時間群 $(\times 30,000)$

神経細胞の核仁 (n1) を構成する Nucleolonema が太くなると共に，その間の緰眼が狭小と なり核仁は增大するが全体として球形を保っ。 核 $(\mathrm{n})$ は輸遊の変形著明, しかし核膜 $(\mathrm{nm})$ 二重棈造は保たれている。

付図 15 (長時間羓 $\times 5,400$ )

神経細胞之外套級肥の境界は全周に亘つて明膫 でないが，神経細肥の核（n）の変形は殆亡゙無 く, 又 Chromatolyse も柽度である。

付図 16 (長時間群 $\times 4,900$ )

神経細胞の細胞賀内に著明な空胞 ( V a c ) を形 成し，蜂窝状に集合する部分と全く不規則な形 に融合し架胞の壁が認められないものとがあ る、細胞貿の諸構造も不鮮明化し，核 (n) は 変形著明, 神経細胞と外峑細胞との境界は不明 嘹である。

af (axonfibril) 㜞索細線維

ax (axon) 軸索

axm (axon membrane) 彯索膜 
cm (cell membrane) 細胞荧

b (droplet) 滴状小体

ER (endoplasmic reticulum) 粗面小胞体

G (Golgi apparatus) $コ$ ル゙ギ体

Gg (Golgi granule) ゴルデ顆粒

Gm (Golgi membrane) ゴルヂ膜

Gv (Golgi vacuole) エ゙ルヂ空胞

i (infolding) 細胞膜の切孔込双

m (mitochondria) ミトロンドリア

mes (mesaxon) 結合膜

$\mathrm{N}$ (Nissl bodies) =ッスル小体

$\mathrm{n}$ (nucleus) 核

nc (nucleus of capsule cells) 外套細胞の核

nf (neurofilament) 神経細線維

nl (nucleolus) 核化

nla (nucleolonema) 核仁糸 nm (nucleus membrane) 核膜

$\mathrm{n}$-Sch (nucleus of Schwann cells) Schwann 氏

細胞力核

V (vesicles) 空胞状構造

$\mathrm{Vac}$ (Vacuole) 空胞

W (whorl structure) 渦状棰造

稿を終るにあたり，御指導，御校閲を賜つた 恩師西端鼠一教授，小林忠義教授に讙んで感謝 の意を表すると共に，終始御懇切なる御指導荱 颙挂をいたがいた鈴木安恒助教授，渡辺陽之輷 助教授，串田弘工学士に梁く感謝いたします。 な特，本諭文の要旨は日本耳鼻咽㬋科学会関 束地方会第26 回大会に打いて報告した。

（原棏到着 $=$ 昭和 34.11 .5 日） 

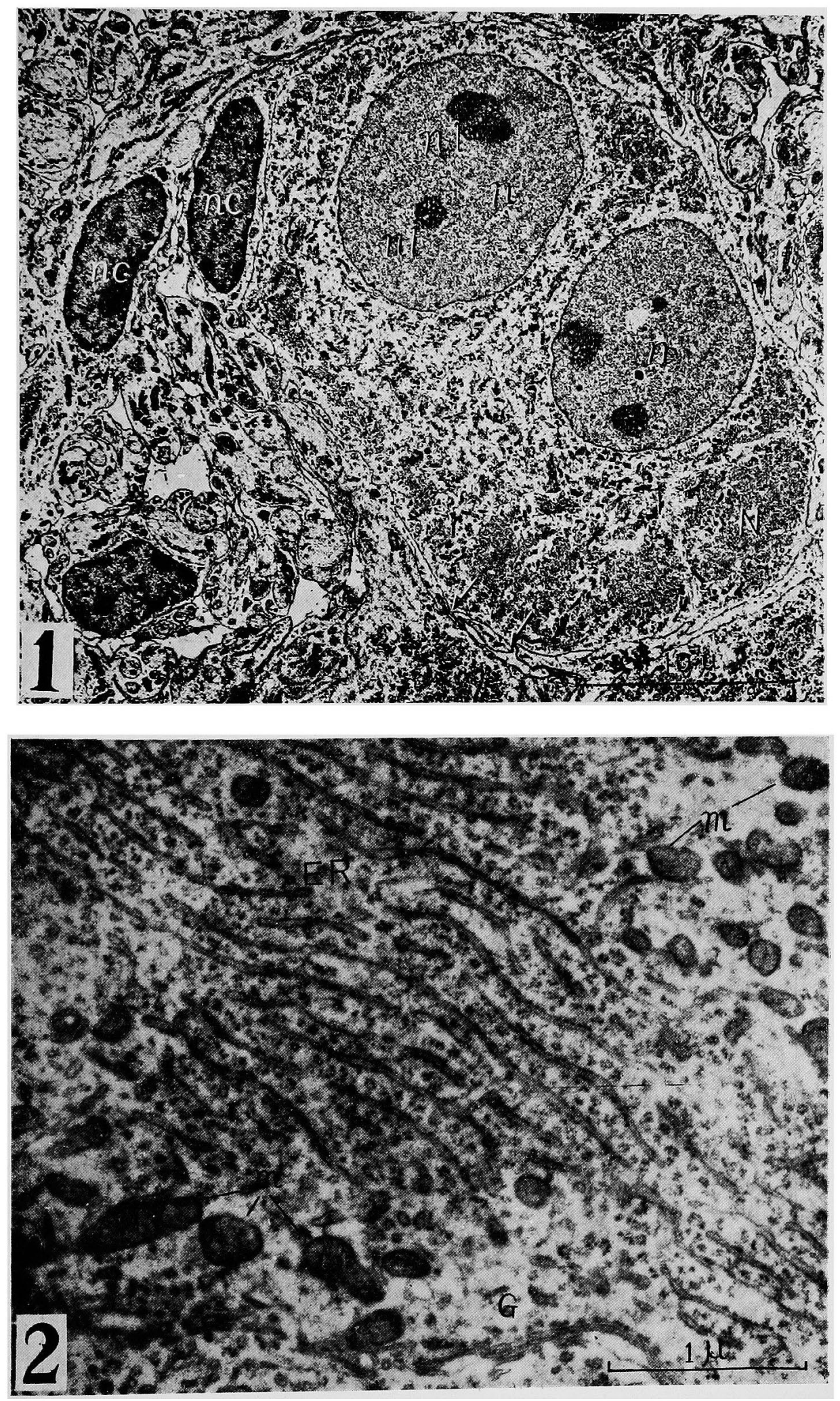

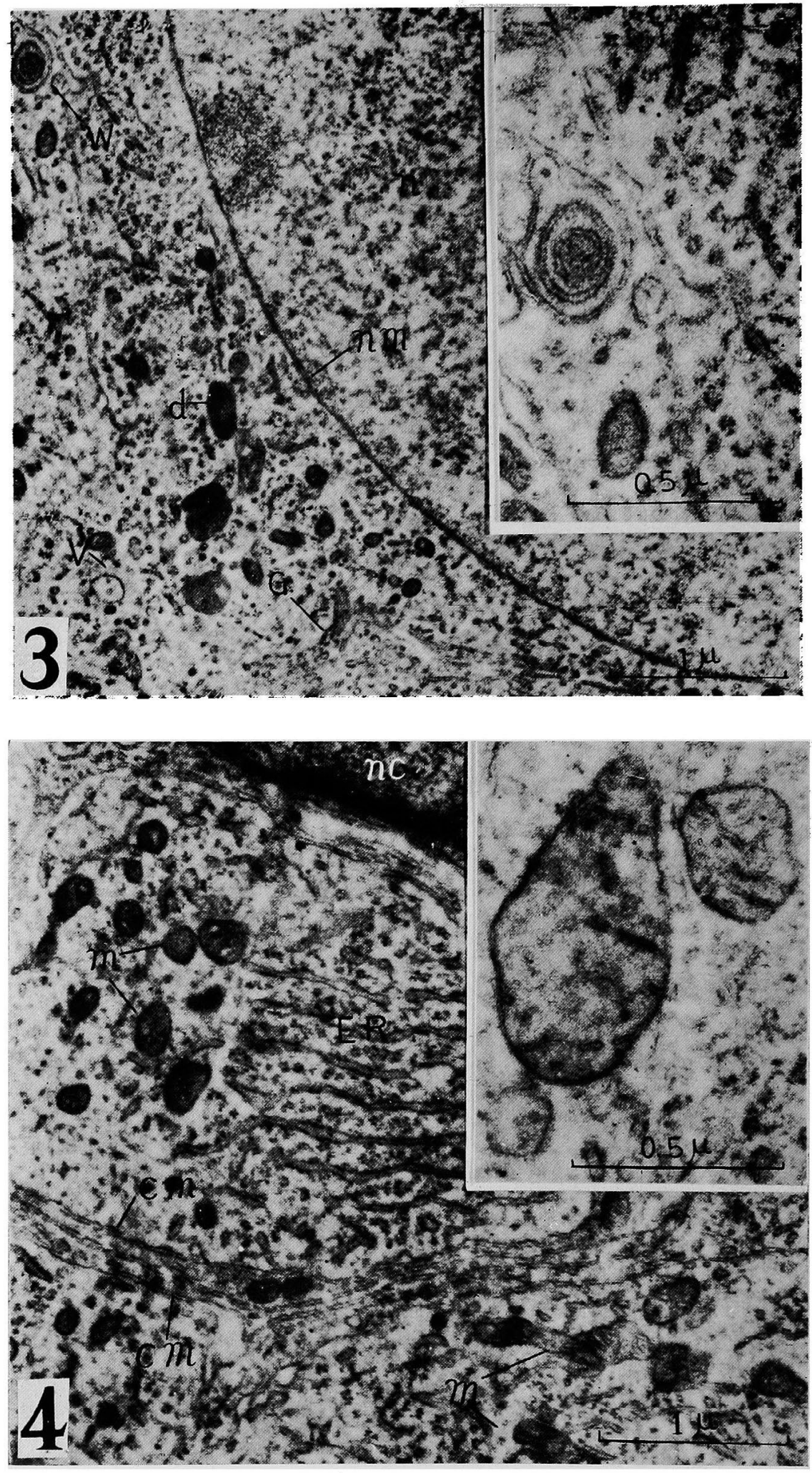

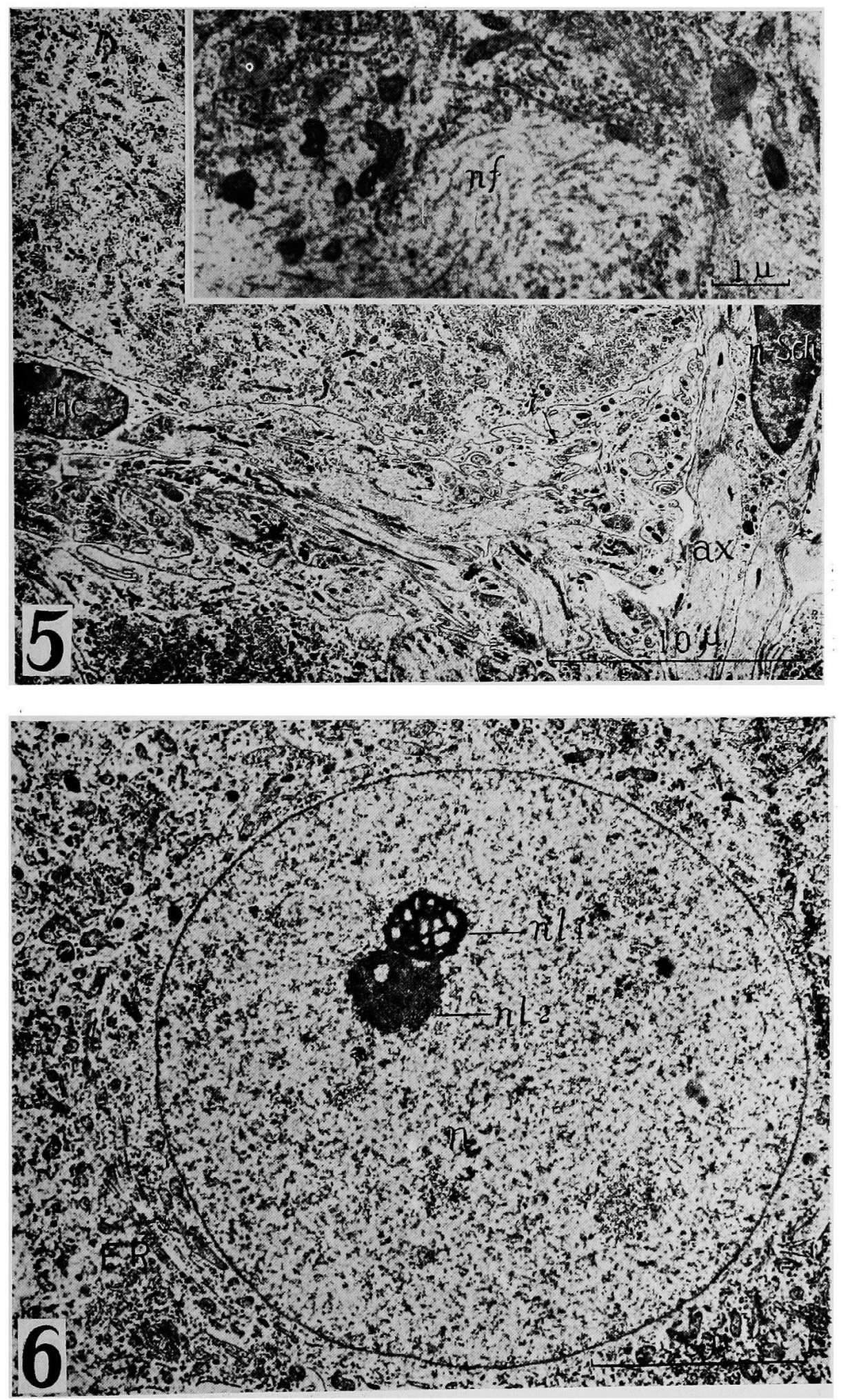


\section{玉 川論文 付 図 (N)}
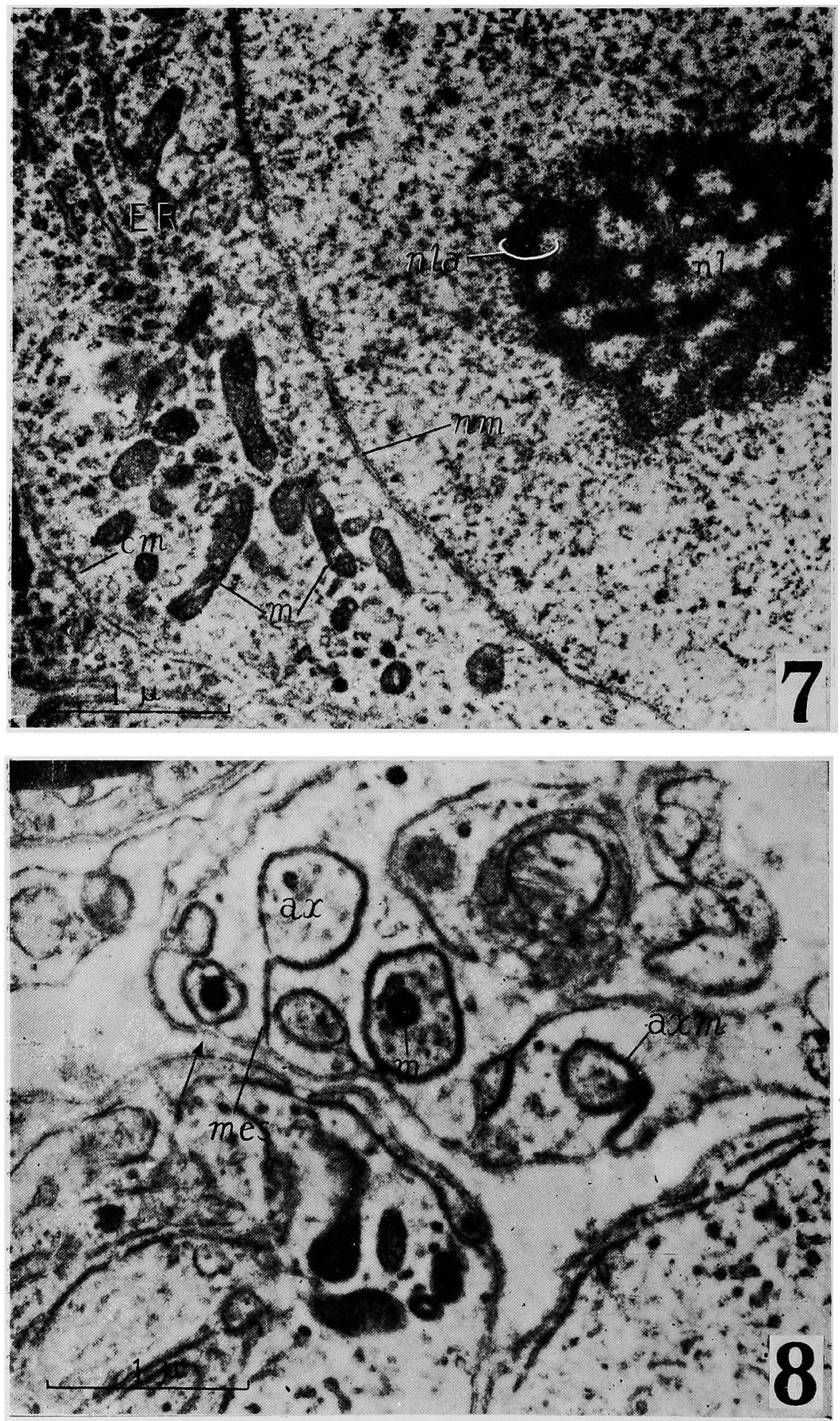

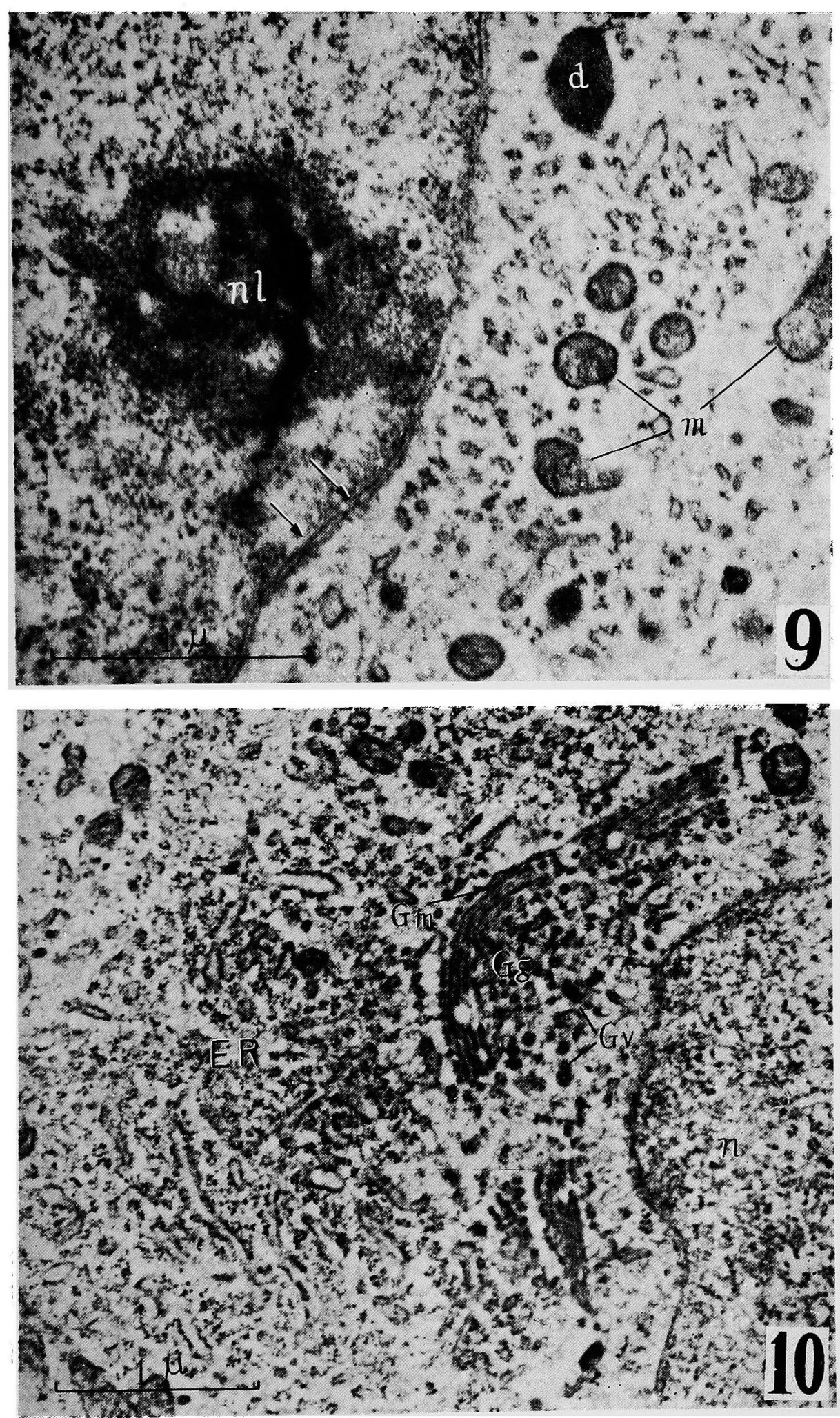

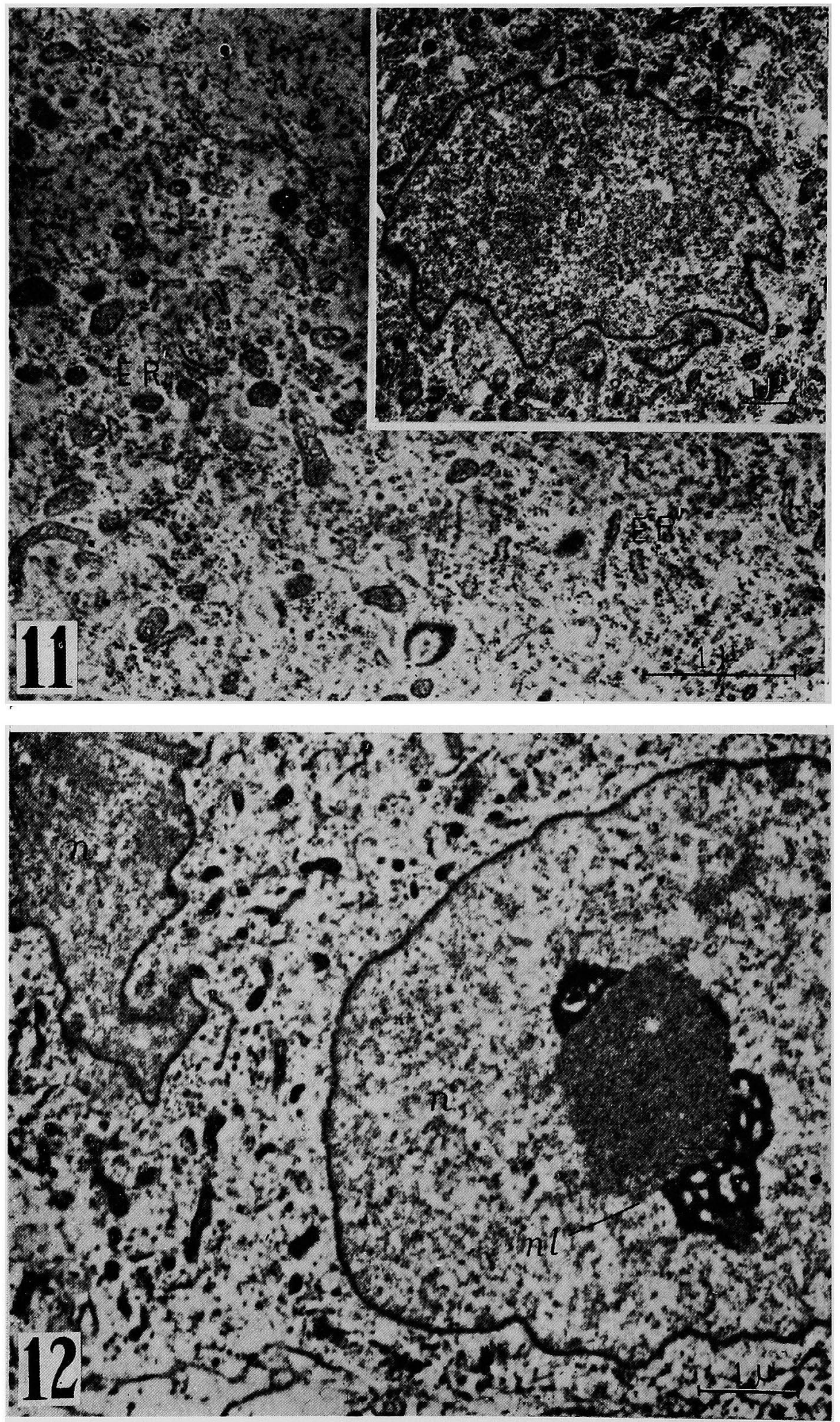

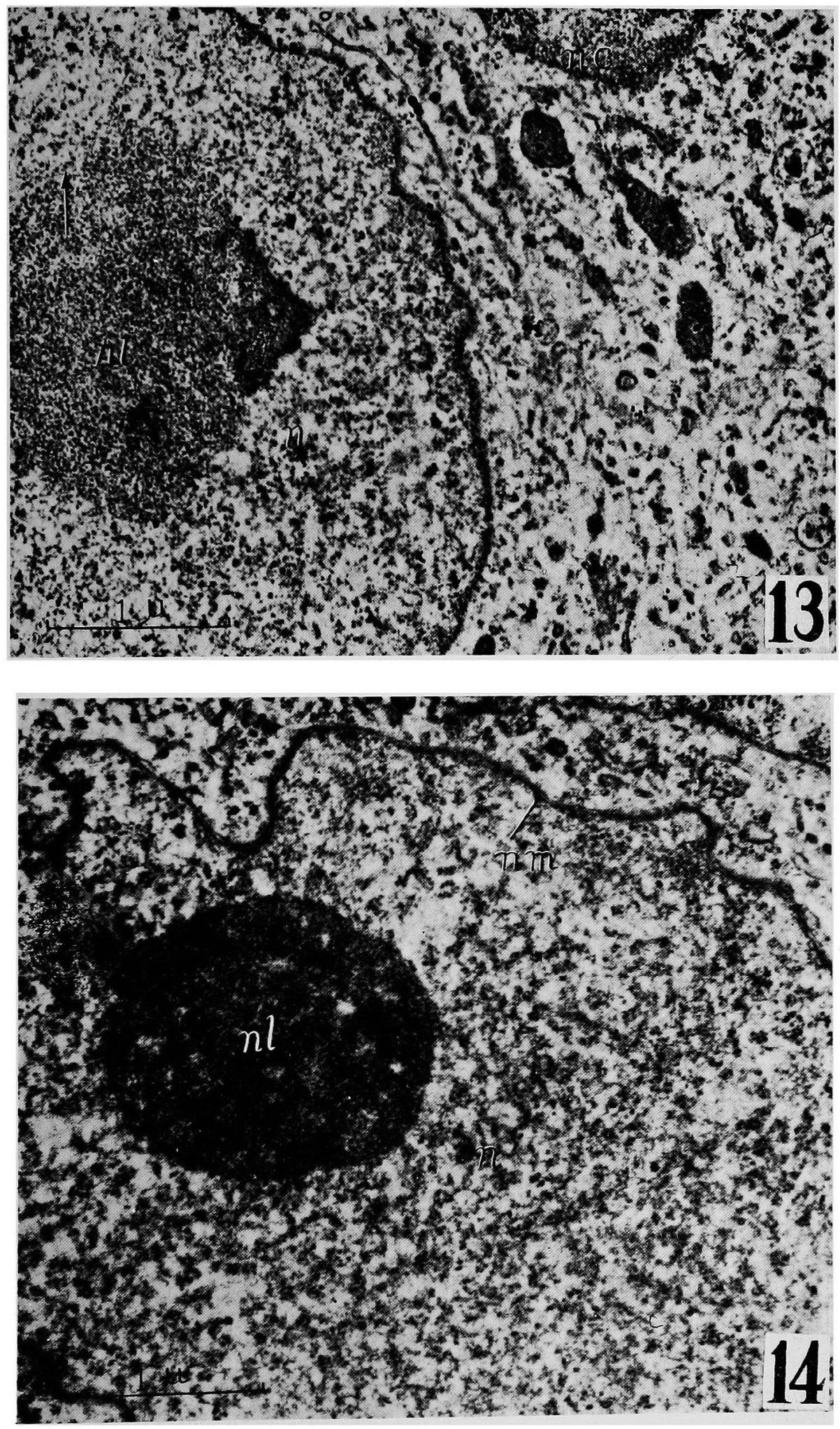

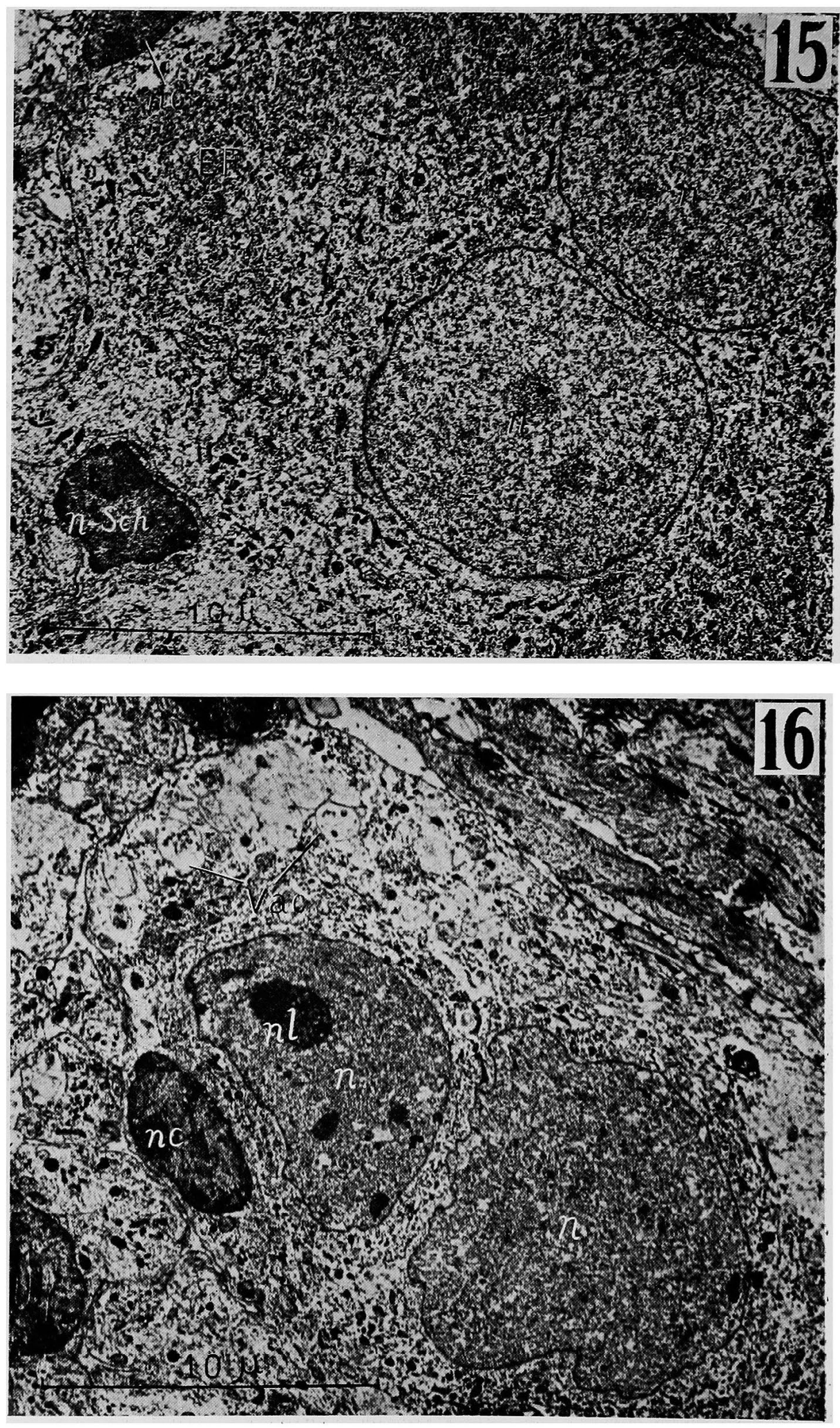